\title{
11. DEPOSITIONAL FACIES OF LEG 30 DEEP SEA DRILLING PROJECT SEDIMENT CORES
}

\author{
George deVries Klein, Department of Geology, University of Illinois, Urbana, Illinois
}

\begin{abstract}
Sediment cores from Leg 30 are subdivided into eight sedimentary facies. The vertical sequence of these facies is controlled by differences in tectonic setting from which the cores were obtained. Three sites $(285,286,287)$ sampled marginal basins, whereas two sites $(288,289)$ were obtained from an equatorial plateau.

The marginal basin facies at Sites 285 and 286 consist of basal sandy turbidites (facies 1) interbedded with mass flow and debris flow conglomerates (facies 2). Within the turbidite intervals, particularly at Site 286 , an upward increase in flow intensity is suggested from the vertically upward increase in coarse-tail graded bedding which in turn is overlain by an interval of facies 2 conglomerates. Such coarsening-upward facies successions mimic the progradational model of submarine fan evolution documented elsewhere. These clastic facies are overlain by biogenic ooze (some reworked by turbidity currents) of facies 3 and they in turn are capped by abyssal red clays (facies 4). At Site 287 in the Coral Sea Basin, the vertical facies succession consists of basal biogenic oozes (facies 3 ) overlain by olive clays (facies 6) and capped by silty and clayey turbidites (facies 5) organized into graded cycles.

The two sites on the Ontong-Java Plateau show a different facies evolution from a basal facies consisting of reworked and mixed volcanic ash and biogenic sediments and chert (facies 8) to an upper facies consisting of biogenic ooze only (facies 7). Reworking by both turbidity and bottom currents is responsible for the admixture of carbonate and volcanic material which are organized into a vertical sequence herein named the volcaniclastic-siltstone-pelagic-carbonate cycle. The cycle consists of a basal interval of graded, fresh volcanic ash which is overlain by a middle interval of biogenic limestone and chert containing parallel laminae, current ripples, and lenticular, flaser, and wavy bedding, and clay drapes. The clay drapes comprising parts of flaser beds consist of altered volcanic ash. The cycle is capped by a biogenic limestone interval. Such cycles are common to oceanic settings where biogenic sedimentation occurs near regions of active volcanism. The facies sequence at Sites 288 and 289 suggests tectonic quiescence for the Ontong-Java Plateau.

The facies sequences in the marginal basins at Sites 285 (South Fiji Basin) and 286 (Hebrides Basin) suggest the following tectonicsedimentary history. During initial development of the marginal basins by sea-floor spreading, the basinal environment was characterized by high slope instability which favored deposition of sediments by turbidity currents. These turbidity currents built submarine fans which prograded toward the basin center as sea-floor spreading continued. As the basin widened, regional slope instability was reduced, and associated turbidity currents were characterized by reduced flow intensity. After spreading ceased, turbidity current activity was minimal, and biogenous sedimentation occurred followed by pelagic red clay deposition once the basin floor subsided below the nanno solution depth. Pelagic sedimentation dominated after termination of spreading. A reversal of sedimentary facies such as that observed in the Coral Sea Basin at Site 287 (and also 210) occurs only if regional tectonism on the edges of the marginal basins renews the supply of clastic sediments.
\end{abstract}

\section{INTRODUCTION}

Deep-sea sediment cores from Leg 30 (Figure 1) were obtained from three marginal basins (South Fiji Basin, Hebrides Basin, Coral Sea Basin) and from an equatorial plateau, the Ontong-Java Plateau. The sediments occurring in these cores are grouped into eight depositional facies based on common sediment types, texture, sedimentary structures, sedimentary sequences, and biogenic structures. These facies conform to the style of facies designations of De Raaf et al. (1965), Walker (1966), Collinson (1969), and Klein et al. (1972) 


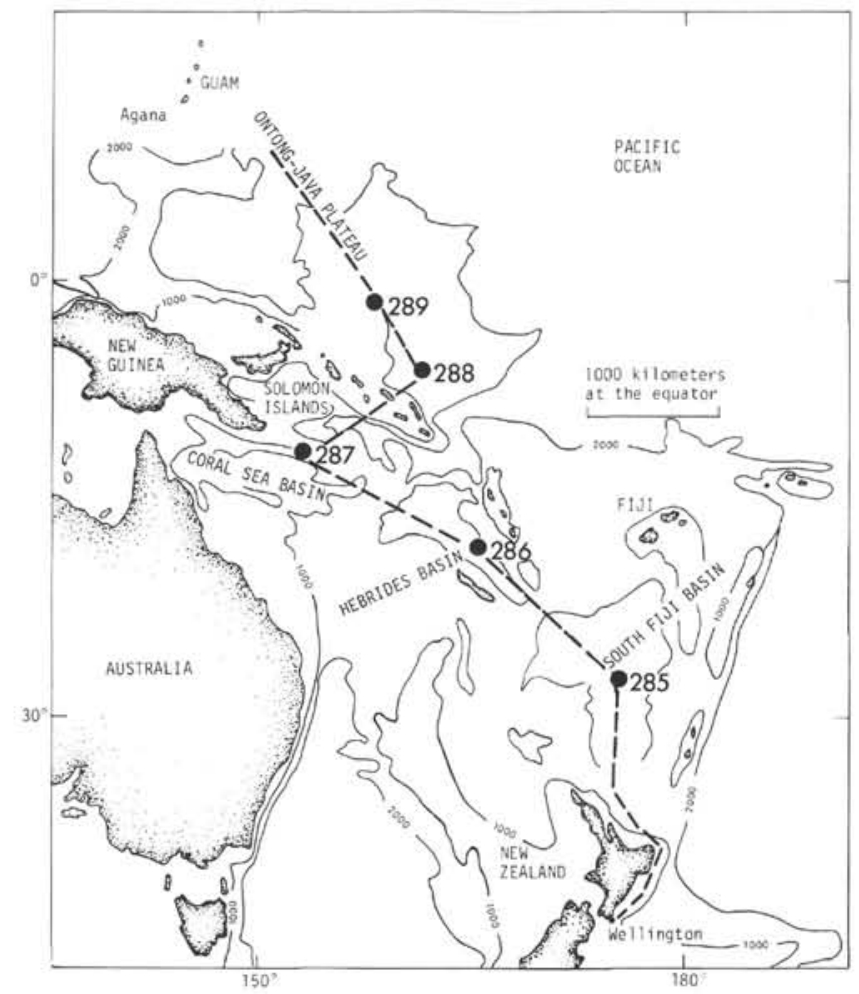

Figure 1. Map of southwest Pacific showing location of sites sampled during Leg 30 and major basins and plateaus sampled during Leg 30.

and compare favorably with those sedimentary facies recognized by Mitchell (1970) from Miocene island arc facies exposed on the New Hebrides Islands. The depositional facies recognized in sediment cores from Leg 30 may in turn serve as a standard for comparison with other marginal basin sediments and oceanic plateau sediments, as well as sedimentary rocks exposed on land which are of similar origin.

\section{SEDIMENTARY FACIES}

\section{Facies 1}

\section{Main Facts}

Facies 1 occurs in the basal portions of cores obtained from Sites 285 and 286 (Figure 1) where they are of middle Miocene and middle and early Eocene age, respectively. The dominant rock type of facies 1 is dark greenish-gray, gray, dark gray, olive-gray, and medium gray silt or siltstone with accessory claystone and sandstone. These textures are organized at several intervals into rhythmites. Dominant petrologic components are glass shards with subordinate amounts of nannofossils and accessory quantities of feldspar, micarb, basaltic hornblende, zeolite, magnetite, and pyrite.

Facies 1 contains a diverse suite of sedimentary structures. These include:

Microcross-laminae: Microcross-laminae are common, occurring in fine to very fine sandstone and accessory siltstone. Individual cross-laminae are contrasted by changes in particle size and color (Figures 2,

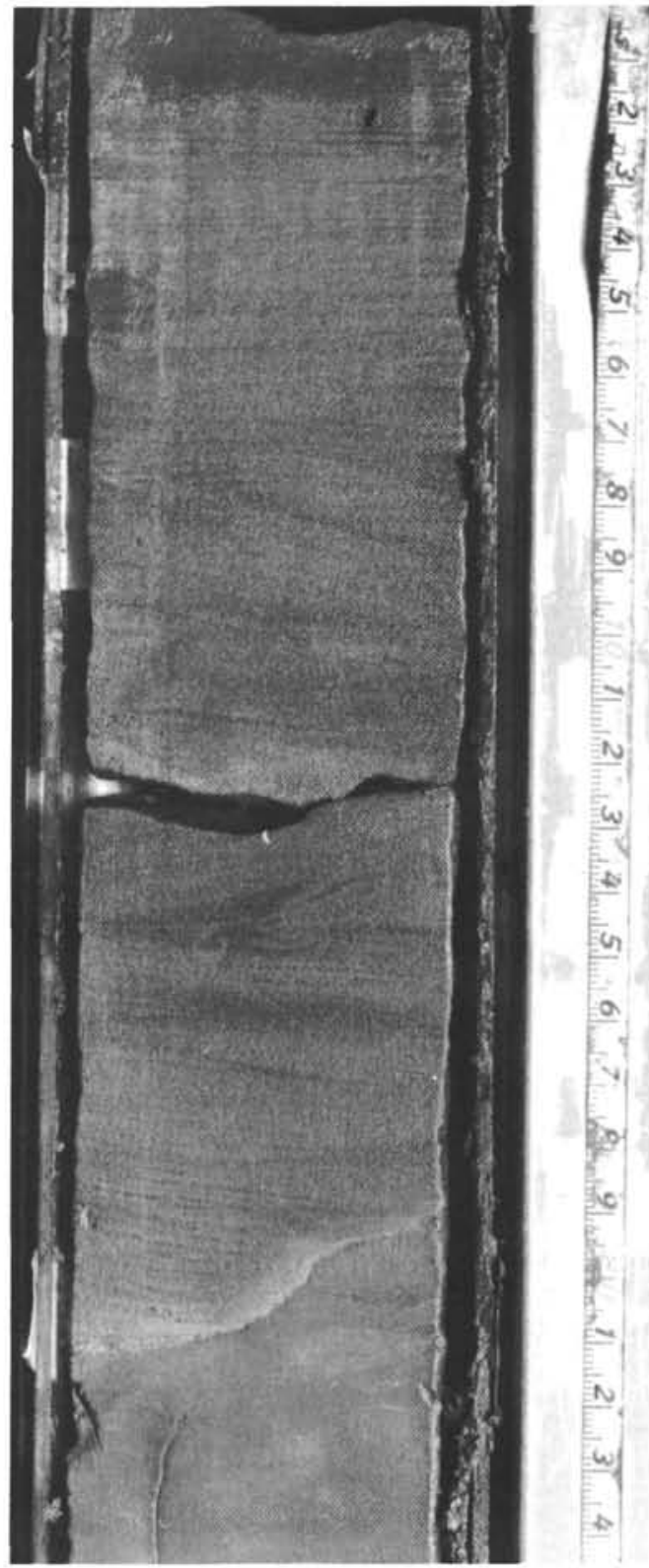

Figure 2. Interbedded basal siltstone overlain by sandstone with sharp basal scour filled with microcross-laminaed sandstone and capped by parallel-laminated sandstone. These structures comprise the top interval of a type 3 sequence overlain by the basal members of the next overlying sequence. Facies 1. 285A-4-3. Scale in cm.

$3,4)$. The microcross-laminae are organized into sets ranging in thickness from 3 to $10 \mathrm{~mm}$ and averaging 6 $\mathrm{mm}$. Most basal contacts of these cross-laminae are in sharp contact with underlying sediments and are observed to grade up into either a parallel-laminated finegrained sandstone (Figure 2), a disturbed slump-fold zone, or a zone of in-phase or sedimentary waves. The slump folds are similar to the slump folds or disturbed zones described as overturned cross-laminae by Moore (1974) from the western Indian Ocean. 


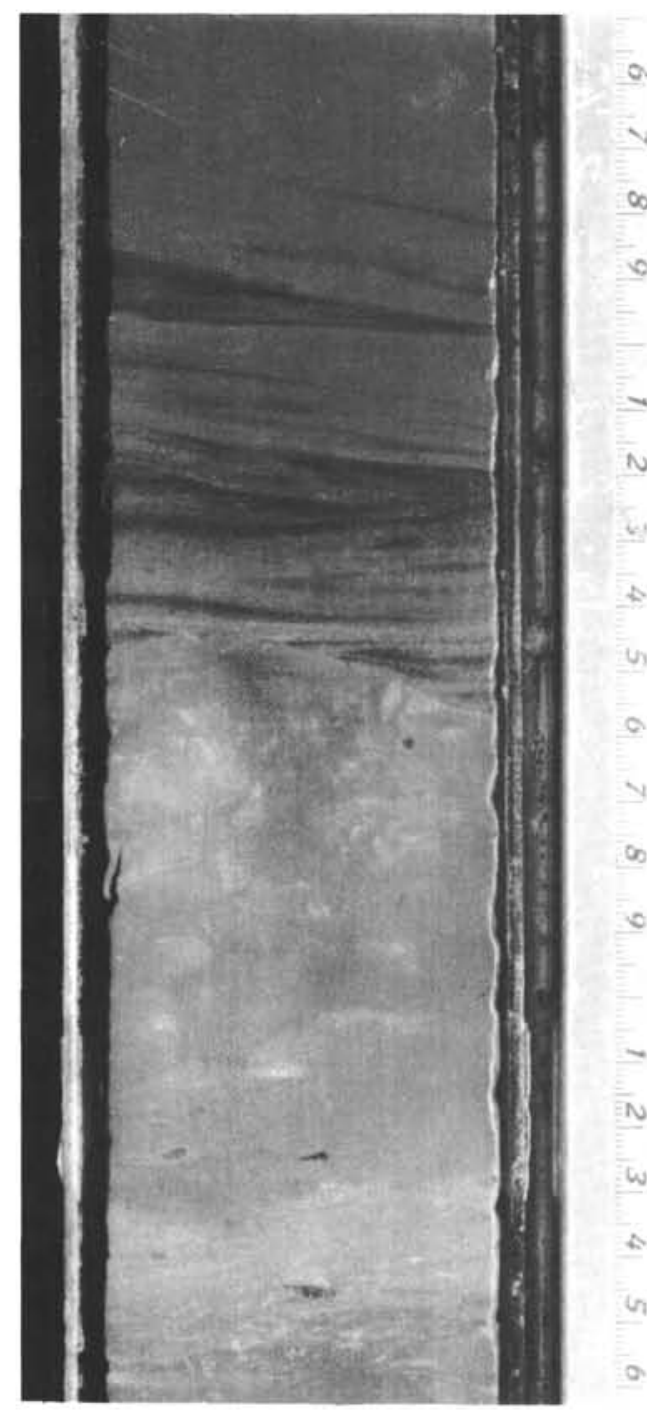

Figure 3. Siltstone with bioturbation overlain at sharp contact with sandstone containing microcross-laminae. Contact separates top interval and basal interval of type 3 sequence. Facies 1. 285A-7-2. Scale in $\mathrm{cm}$.

Climbing microcross-laminae were observed with the angle of climb averaging $5^{\circ}$.

Parallel laminae: Parallel laminae are common, occurring in medium, fine, and very fine sandstones. The laminae are visible because of textural sorting into different size grades of sand, or by color differences. The laminae range from 0.5 to $2.0 \mathrm{~mm}$ in thickness (Figures $5,6)$.

Parallel laminae occur as sets associated with either bioturbated mudstones or are underlain by microcrosslaminae and graded beds. They also occur with in-phase (or sedimentary) waves in one horizon.

Ripple bedforms: Current ripple bedforms, preserved as asymmetrical wavy lamination with internal microcross-laminae, occur in facies 1 . Mean wavelength is 20 $\mathrm{mm}$, and mean amplitude is $2 \mathrm{~mm}$, yielding a mean ripple index of 6.7. These ripple forms occur in both medium and fine sand.

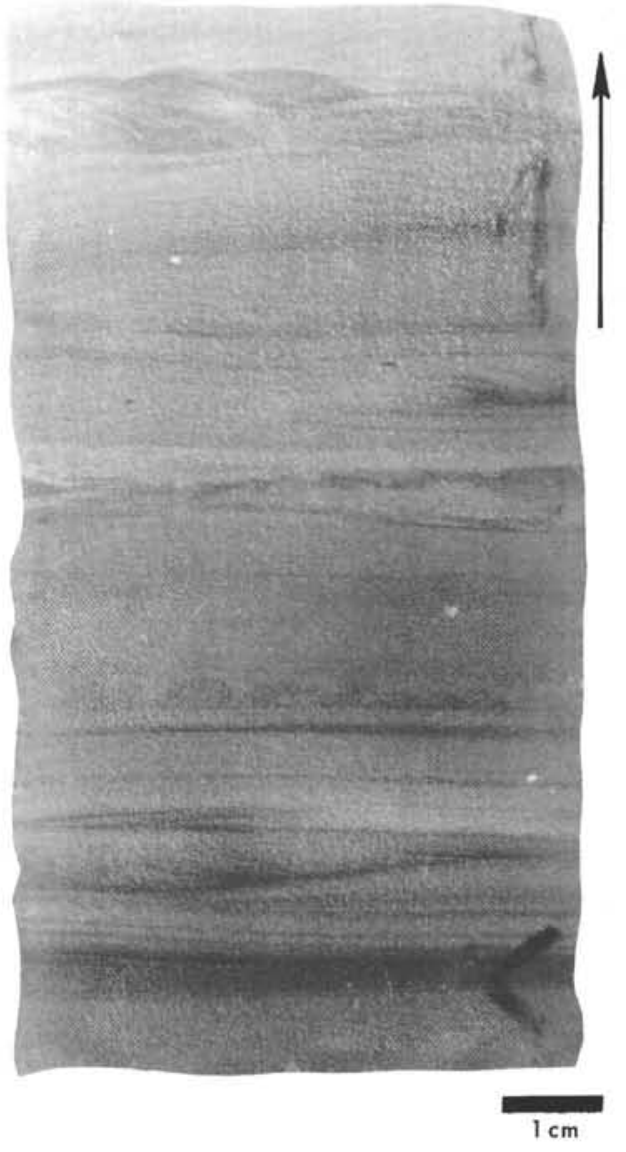

Figure 4. Sandstone showing interbedded parallel laminated and microcross-laminae and trace of ripple bedform (at top). Facies 1. Sample 286-7-3, 127-140 cm.

Slump folds: Slump folds occur in a few layers of fine sand and coarse silt. Normal, sheared, and overturned folds are present (Figures 7, 8). The folds are accentuated by textural sorting of laminae and by color changes. The folds are also partly disrupted, so pullapart fragments of dark olive siltstones occur scattered in disturbed olive-gray sandstone.

In-phase waves: Symmetrical in-phase waves (see Southard, 1971, for definition) resembling sedimentary waves of Simons et al. (1965) occur in Sample 286-25-3, $132-150 \mathrm{~cm}$. The in-phase waves consist of individual laminae of either dark gray, light gray, or medium gray very fine sand interlaminated with fine sand, very fine sand interlaminated with silty sand, and medium sand containing laminae enriched with opaque minerals (Figure 9).

The in-phase waves are internally laminated with laminae parallel to the sinusoidal waveforms. Wavelengths range from 1.0 to $6.0 \mathrm{~cm}$ (mean of $1.6 \mathrm{~cm}$ ) and wave amplitudes range from 1.0 to $5.0 \mathrm{~mm}$ (mean of 2.2 $\mathrm{mm}$ ). The in-phase waves normally overlie parallel laminae or massive graded beds, and in turn grade upward into slump folds.

Antidune cross-stratification (?): Possible antidune cross-stratification was observed in Samples 286-25-1, $129-133 \mathrm{~cm}$ and $286-25-3,132-150 \mathrm{~cm}$. These strata occur associated with slightly disrupted slump folds or 

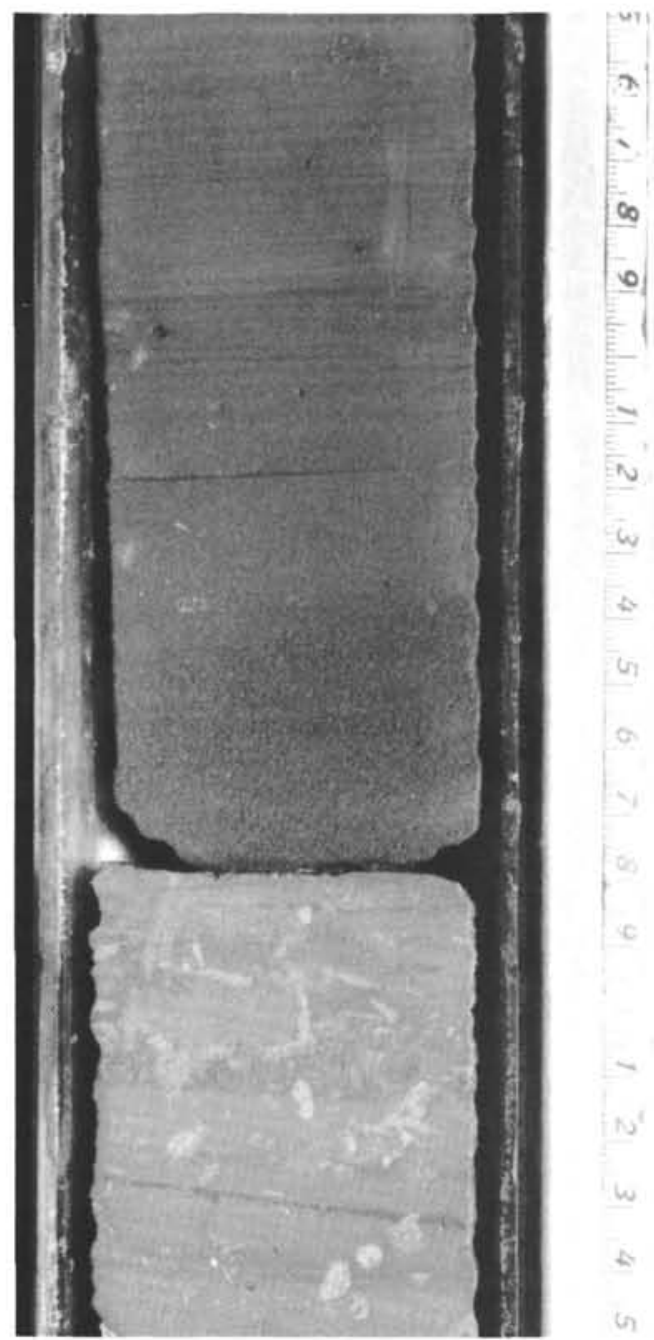

Figure 5. Bioturbated siltstone and sandstone showing graded bedding and overlying parallel laminae. Sandstone segment shows basal intervals of a type 2 sequence. 286-25-4. Scale in $\mathrm{cm}$.

overturned folds and show a progressive upward increase in dip angle (Figure 7), a criterion suggested by Hand (1969) and Hand et al. (1969) for recognizing antidune cross-stratification. The antidune cross-strata also occur in the troughs of in-phase waves and again show the same upward increase in dip angles. They occur in poorly sorted coarse sand and in medium sand. The laminae are also contrasted by color.

Graded bedding: Facies 1 also contains coarse-tail and content graded bedding, particularly at Site 286 . Graded beds range in thickness from $3 \mathrm{~mm}$ to 1.0 meter. Particle size ranges from medium coarse sand to medium sand through fine sand into silt in coarse-tail graded beds, and from medium sand through silt in normallygraded beds. Basal contacts of graded beds are sharp (Figures 10,11) locally channeling into underlying graded bedding (Figure 12) and are intruded by flame structures at the basal contact (Figures 10,11). Graded beds are overlain by parallel laminae or by in-phase waves (Figures 5, 7).

Massive bedding: Massive bedding is common to some sandstones and is associated with graded sandstones.

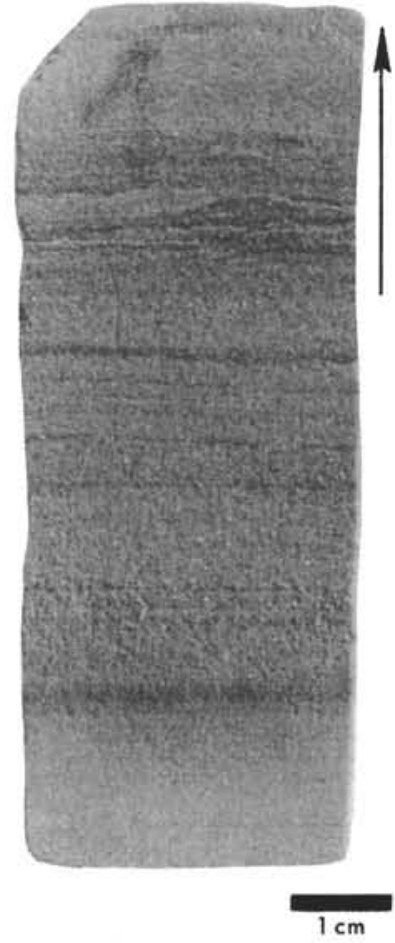

Figure 6. Parallel laminae in sandstone. Facies 1. Sample $286-17-5,110-119 \mathrm{~cm}$.

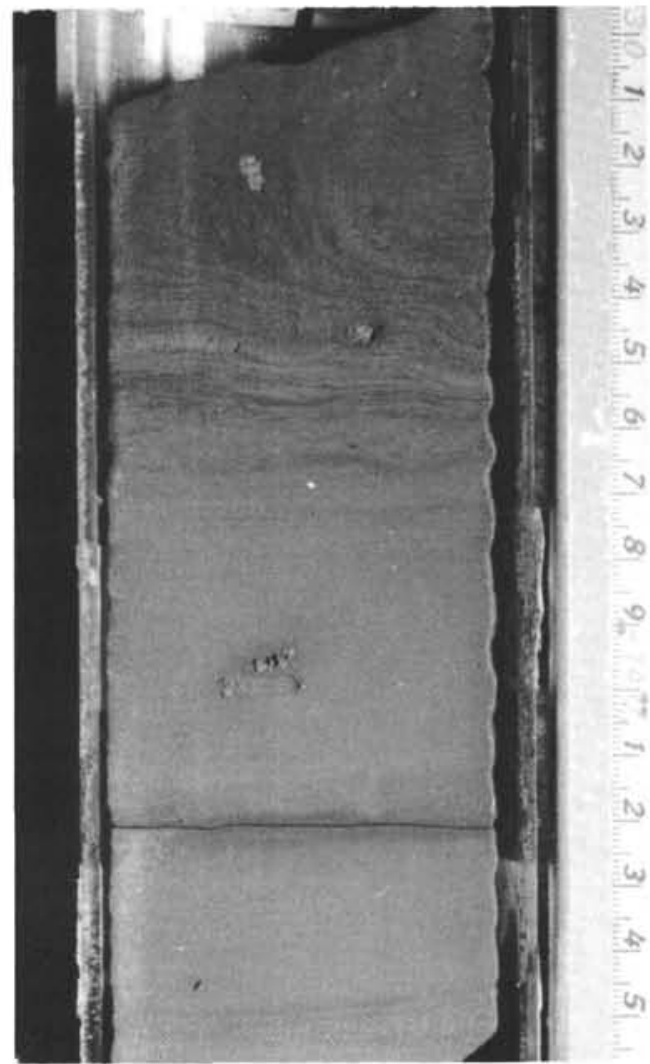

Figure 7. Sandstone showing basal parallel laminae grading upward into possible inphase waves of low amplitude with associated antidune cross-stratification and nearly overturned antidune cross-stratification. Facies 1. 286-25-1. Scale in cm. 


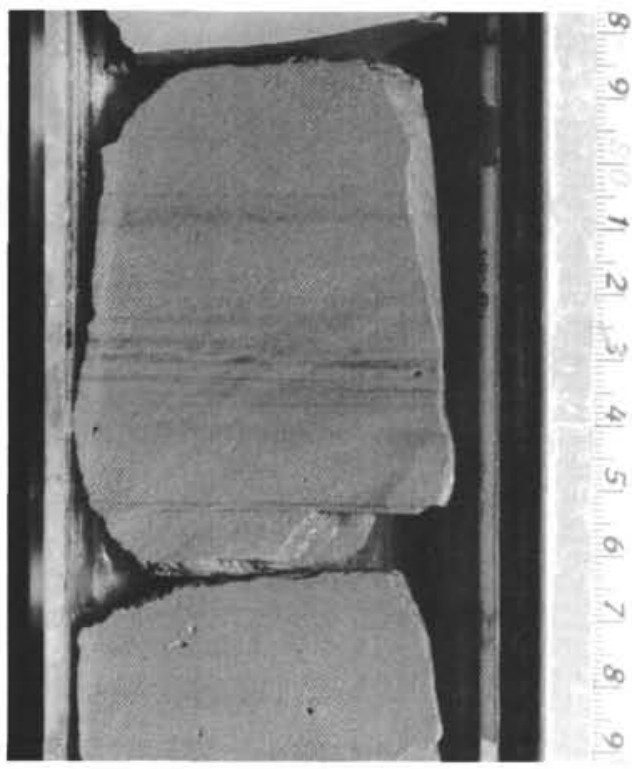

Figure 8. Fine-grained sandstone showing parallel lamination and convolute laminae. Facies 1. 286-23-2. Scale in $\mathrm{cm}$.

Flame structures: Flame structures occur at the base of several graded beds at Site 286 (Figures 10, 11). Here dark olive-gray sandstones are intruded by olive-gray silty sandstones.

Dewatering pipes: Vertical pipes of broadly sinusoidal shape occur in medium fine sand at Site 286 and are particularly well developed in Sample 286-27-2, 132-140 cm. The pipes are olive-gray, whereas the sandstone into which they are set is medium olive-gray (Figure 13). The pipes are filled with fine sand containing about 5\% opaque minerals, thus accounting for their darker hue. Pipe occurrence is limited to sediments underlying coarse-tail graded beds intruded by flame structures, suggesting rapid application of overburden stress which expelled the water to produce the pipes.

Biogenic structures: Biogenic structures are also common to facies 1 and occur mostly in silty claystones and clayey siltstones. Most biogenic structures are represented by variable degree of mottling, but excellent preservation of Chondrites and Zoophycos, Planolites and Teichnicos occurs. Some parallel-laminated sandstones contain an "s"-shaped track of Spirophycos on the bedding planes.

Faunal components in facies 1 are nannofossils, traces of foraminifera and radiolarians, as well as scattered pollen grains and wood chips. Two genera of reworked shallow water foraminifera occur at several horizons. These are abraded forms of both Amphistegina lessoni and Elphidium sp. in Samples 285A-1-1, 120-130 cm and 285A-1-6, 136-140 cm. Abraded forms of Asterigerina and Amphistegina occur in 286-19, CC, 286-30, CC, and $286-26-3,38-40 \mathrm{~cm}$. These reworked foraminifera occur with well-preserved deep-water forms.

\section{Sedimentary Sequences}

The dominant characteristic of facies 1 is the organization of textures, sedimentary structures, and

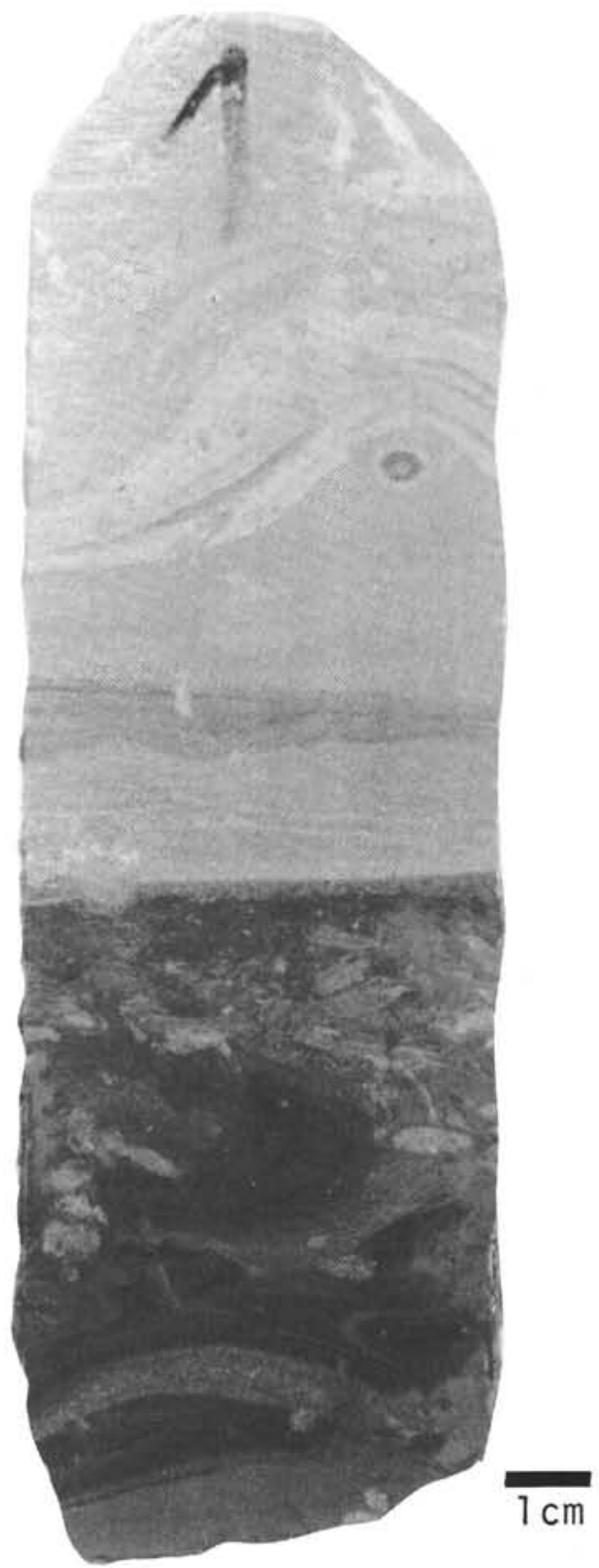

Figure 9. Partial type 5 sequence. Bioturbated siltstone (dark) is overlain by a sharp base, a $2 \mathrm{~cm}$-thick graded bed containing undulatory laminae which grades up into a thin zone of in-phase waves which is capped by parallel laminae. Facies 1. Sample 286-25-3, 132-150 cm.

biogenic structures into five types of sedimentary sequences (Figure 14).

Type 1 sequence: This sequence occurs mostly at Site 286 and is the typical five-interval $\left(\mathrm{T}_{\mathrm{a}-\mathrm{e}}\right)$ sequence documented from ancient turbidites by Bouma (1962). The basal contact of the sequence is sharp and is overlain by interval "a," a graded bed ranging from coarse to medium sand at the base to medium fine sand at the top. This interval passes upward into a medium fine sand which is parallel laminated (interval "b") and in turn grades upward into a fine sand containing microcrosslaminae (interval "c") or climbing ripple microcross- 


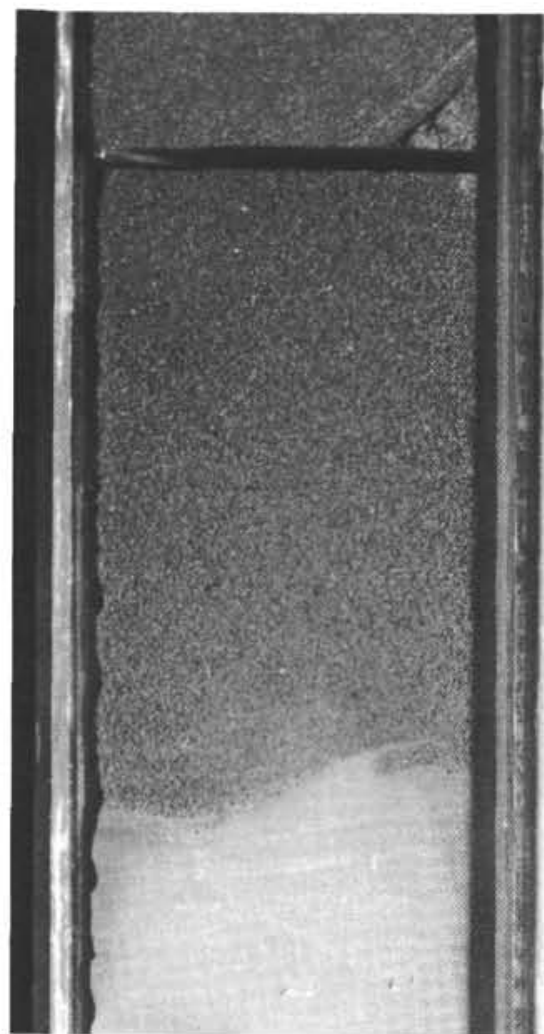

Figure 10. Graded sandstone with flame structure overlying siltstone. Facies 1. 286-26-2. Scale in $\mathrm{cm}$.

laminae with a low angle of climb. This interval passes upward into a finer grained (silty) parallel-laminated interval and is capped by a silty claystone which is either bioturbated or devoid of structures. These sequences range in thickness from 21 to $71 \mathrm{~cm}$, with a mean of 41 $\mathrm{cm}$. Four type 1 sequences were identified at both Sites 285 and 286.

Type 2 sequence: This sequence is a partial type of Bouma sequence containing intervals "a," "b," and "e" (Figure 4). The basal part of the sequence consists of a sharp scoured contact which is filled by a basal graded bed (both coarse-tail and normally graded). The grain size ranges from fine sand at the base and grades into very fine sand, or from medium sand and grading into fine and very fine sand. The graded zone is overlain by a very fine sand and silty sand which is parallel laminated, and this zone in turn is overlain by a bioturbated siltstone.

Type 3 sequence: This sequence consists of a sharp base overlain by microcross-laminated sand (Figure 2). Parallel-laminated sand capped with bioturbated and mottled clayey siltstones overlie the basal microcrosslaminae. The microcross-laminae contain size-sorted laminae of fine sand and very fine sand, whereas the parallel laminae show size sorting from very fine sand to coarse and medium silt. This sequence ranges in thickness from 10 to $125 \mathrm{~cm}$, with a mean thickness of $59 \mathrm{~cm}$. Type 3 sequences are the dominant sedimentary motif at Site 285. Partial sequences of microcross-laminated sands grading into bioturbated intervals also occur.

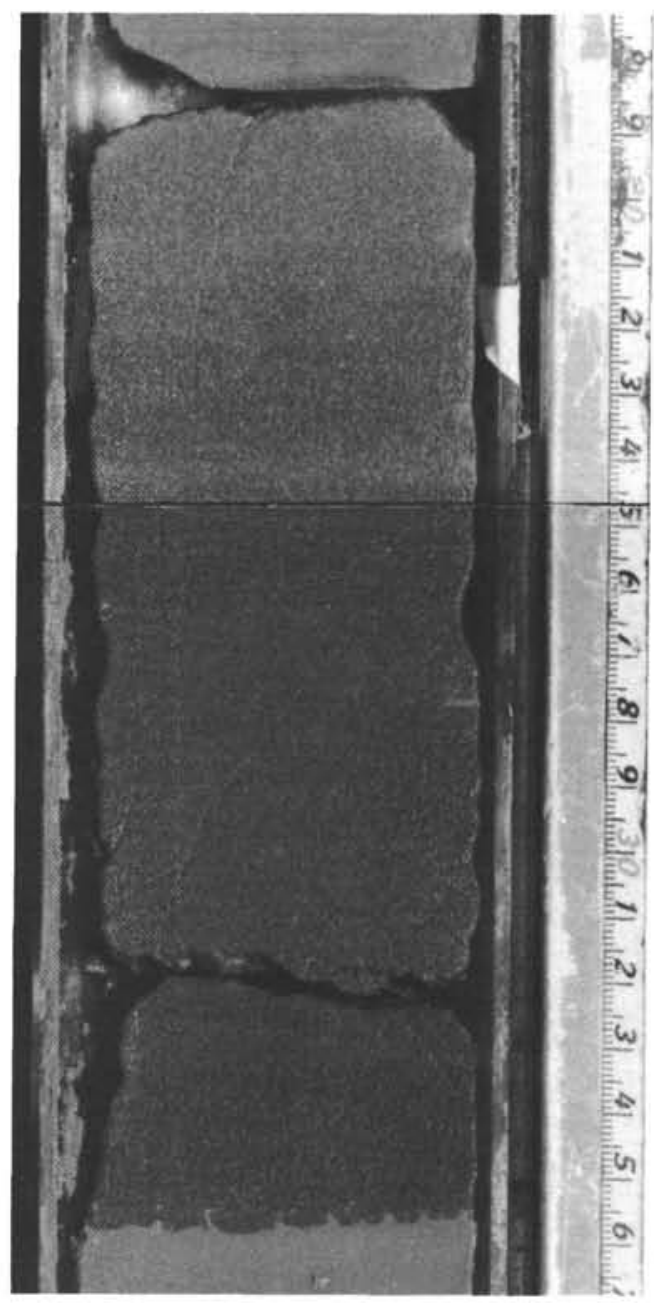

Figure 11. Graded sandstone with basal flame structures grading into faintly parallel-laminated interval. Type 2 sequence. Facies 1. 286-29-2. Scale in $\mathrm{cm}$.

This sequence may appear to be identical to the partial $T_{c-e}$ Bouma sequence. However, not all the type 3 sequences sampled at Sites 285 and 286 show an upward reduction in particle size, and in one interval (286-25-2, $105-137 \mathrm{~cm}$ ) the microcross-laminated interval grades up into a parallel-laminated zone and then grades upward into a microcross-laminated sand before grading upward again into a bioturbated siltstone. The contacts between the cross-laminae and parallel laminae are gradational, suggesting that changes in the volume of sediment during uniform flow would produce this alternation of types of laminae. The parallel laminae were probably produced during lower volume episodes of sediment supply, whereas the current ripples were formed during a higher volume episode of sediment supply. This interpretation fits experimental observations concerning development of parallel laminae and ripples by Shepherd et al. (1973).

Type 4 sequence: This sequence occurs only at Site 286 and ranges up to $240 \mathrm{~cm}$ in thickness. It consists of four intervals. The basal contact is sharp and has been resculptured into flame structures. This contact is over- 


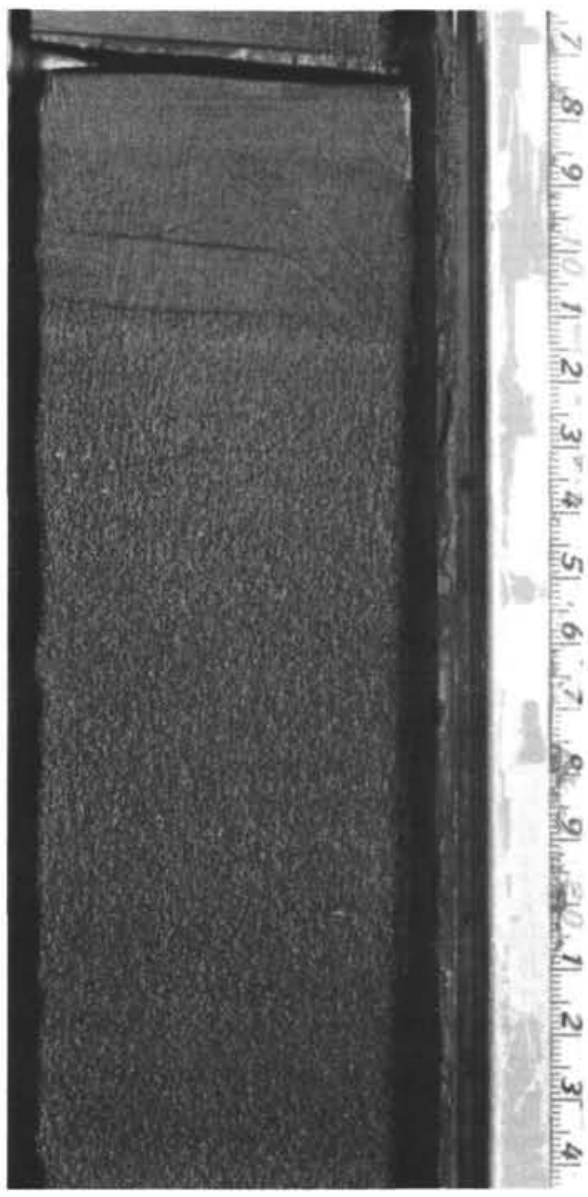

Figure 12. Multiple graded-bedded sandstone; upper-graded interval grades upward into parallel-laminated interval. Type 2 sequence. Facies 1. 286-26-3. Scale in $\mathrm{cm}$.

lain by both normally-graded and coarse-tail graded beds containing particle sizes ranging from coarse sand through very fine sand. This interval is overlain by parallel-laminated sand which also contains internal convolutions and low-amplitude in-phase waves (e.g., Figure 8). Overlying this parallel-laminated sand is a finer grained sand containing dewatering pipes. Bioturbated siltstones cap the sequence.

Type 5 sequence: A fifth sequence observed only at two levels at Site 286 is partly like the sequence of structures observed by Provo (1973) from the Devonian of New York. The partial type 5 sequences at Site 286 consist of a sharp basal contact, a graded interval ranging from coarse sand grading into medium sand, overlain by in-phase (or sedimentary) waves. These in-phase waves are overlain by a parallel-laminated interval (Figure 8). The Site 286 sequences differ from those reported by Provo (1973) only in that the upper "c," "d," and "e" intervals are missing.

\section{Interpretation and Depositional Mechanics}

Faunal data suggest that facies 1 was deposited in deep-water environments (approximately $4500 \mathrm{~m}$ ) at about or immediately above the nanno solution depth. Association of shallow-water foraminifera in this facies

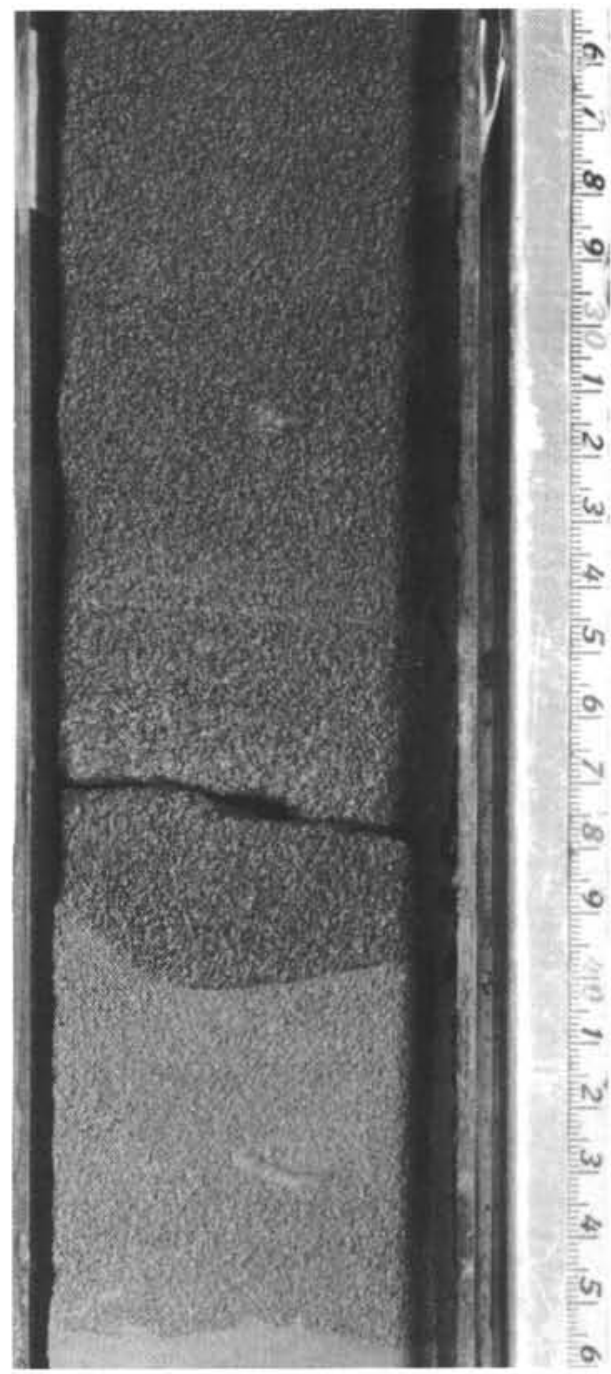

Figure 12. (Continued).

with deep-water fauna suggests reworking of sediments from both shallow-water source areas and deep-water sources. Mixed algal fragments, plant debris, and bryozoan fragments from the interbedded conglomerates of facies 2 confirm such a source derivation. Such data imply both rapid influx of sediment as well as a system of gravitational deposition. Turbidity currents are the most probable mode of transport for this facies.

The depositional rates of the turbidites from facies 1 ranges from $120 \mathrm{~m} / \mathrm{m}$.y. at Site 286 to $200 \mathrm{~m} / \mathrm{m}$.y. at Site 285 (Chapters 4 and 3, this volume). Fluctuations in depositional rates and of flow intensity characterize these turbidity currents. Turbidites containing coarsetail grading, in-phase waves, antidune cross-stratification, and flame structures appear to have been deposited rapidly by high-intensity current systems, whereas the turbidites containing content grading, parallel laminae, and microcross-laminae appear to have been deposited at a slower depositional rate by low-intensity turbidity currents. Rapid influx of some of the Site 286 turbidites was characteristic as indicated by preserved soft-sediment structures such as flame structures and dewatering pipes, which were triggered by rapid compaction immediately on rapid burial. These features are particularly common to the type 4 sequences. 


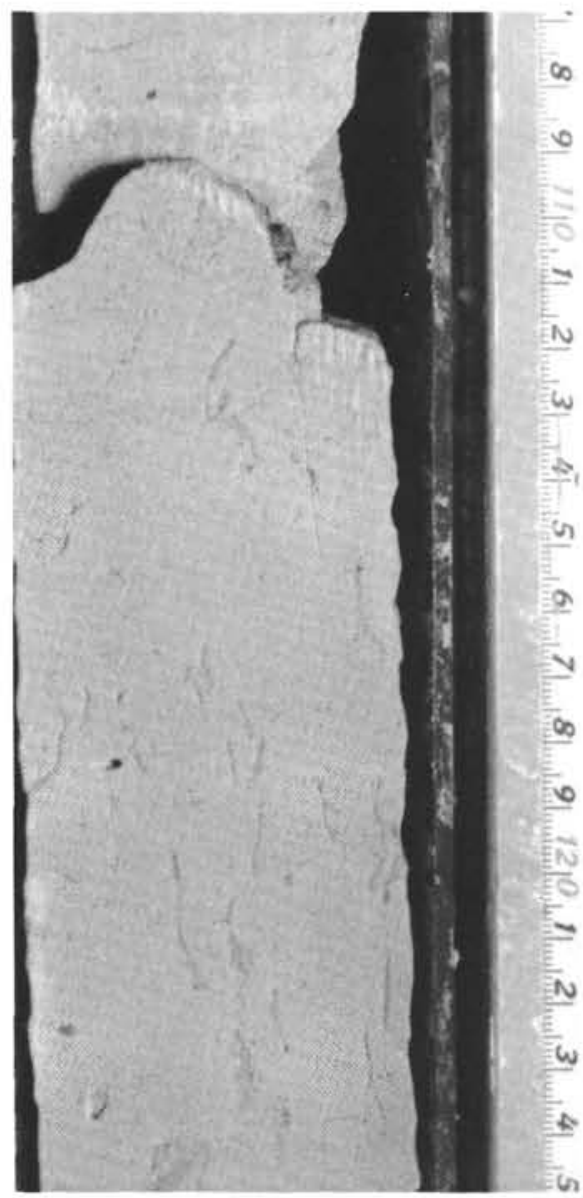

Figure 13. Dewatering pipes in finegrained sandstone. Facies 1. 286-27-2. Scale in $\mathrm{cm}$.

A turbidite origin is also confirmed from the limited occurrence of the type 1 sequences and the more widespread occurrence of type 2 sequences. The type 3 sequence, although mimicking the Bouma $T_{c-e}$ sequence, requires further explanation. The crosslaminated and parallel-laminated intervals occur in sand of identical particle size distribution; these structures are gradational in set contact and alternate back and forth. Experimental observation of such parallel laminae produced by a uniform, even flow by Shepherd et al. (1973) suggests that changes in sediment volume produces this alternation, rather than decrease in flow regime or flow intensity. Whether the interbedding of microcrosslaminae and parallel laminae in the type 3 sequences is produced by turbidity currents or by bottom currents comparable to contour currents (Heezen et al., 1966; Bouma, 1972) could not be established from either Sites 285 and 286 where such sequences are common. Probably, a dilute phase of turbidity current deposition produced these sequences.

Not all the parallel-laminated intervals were deposited by a single turbidity current depositional event, as indicated by the recovery of Spirophycos traces on the bedding planes of several parallel-laminated sediments from Site 285. Their occurrence implies that between deposition of a lamina, sufficient time existed for grazing organisms to rework the bottom sediments.

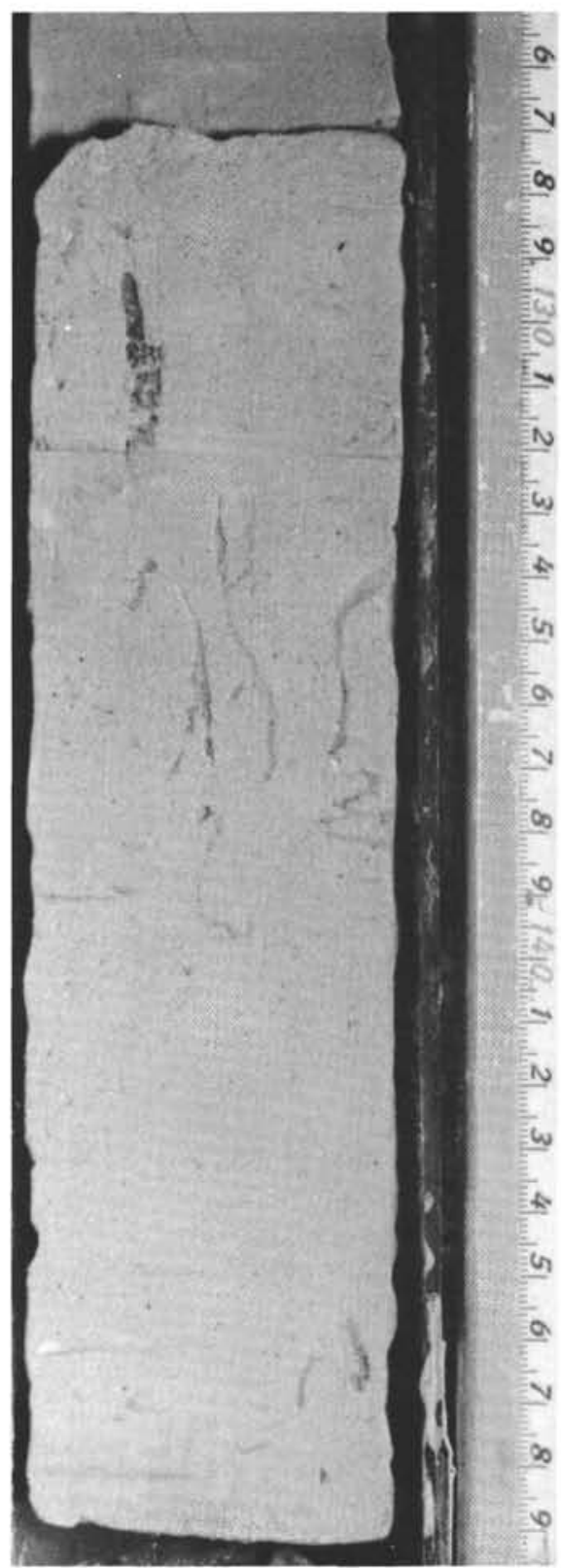

Figure 13. (Continued).

The association of structures, textures, and sequences reported herein and the mechanisms for emplacement discussed above suggest that deposition of facies 1 sediments was in a submarine fan environment. The interbedding of coarse-tail graded turbidites with those of normal grading at Site 286 suggests alternating rapid and slow depositional rates of both high- and lowintensity turbidity currents in the suprafan and leveed upper fan environment where higher slope angles could accommodate the coarse-tail graded turbidites. These coarse-tail graded turbidites are usually overlain and interbedded with mass flow and debris flow conglomerates of facies 2. At Site 285 and the lower portions of Site 286, deposition appeared to be more consistent with normally-graded turbidity currents on the lower fan environment of Normark (1970). Such an environment is consistent with the postulated lower rates 
BOUMA

SEQUENCE

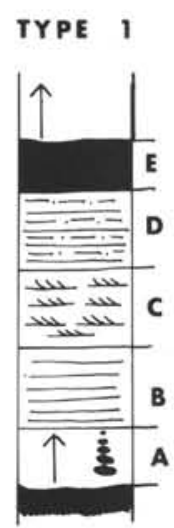

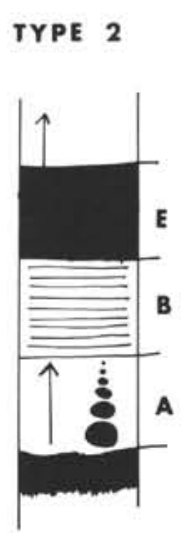

TYPE 3

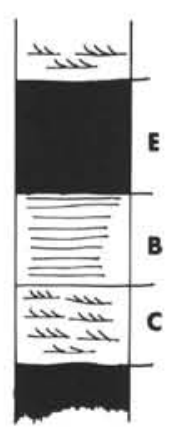

TYPE 4

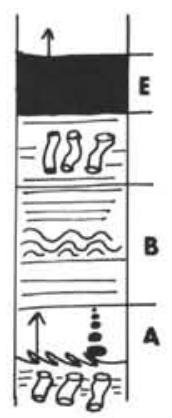

TYPE 5

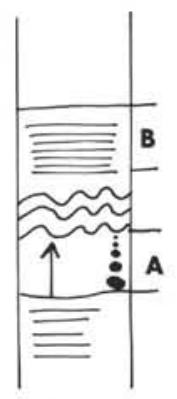

Figure 14. Sedimentary sequences of textures and structures in facies 1, Leg 30 sediment cores. Sequences as described in text.

of deposition for the normally-graded turbidites. Facies 1 , therefore, appears to straddle a range of submarine fan environments which are discussed below in the section on facies sequences.

\section{Facies 2}

\section{Main Facts}

Facies 2 occurs only at Site 286 and is middle Eocene in age. It occurs as three interbedded units within a thicker section of facies 1 in Sections 286-21-1 through 286-22-4, 286-26-4, and 286-29-4.

This facies consists of a dark greenish-gray pebblegranule conglomerate. The gravel clasts consist of basalt, pumice, quartz, feldspar, pyroxene, andesite, hornblende, altered volcanic rock fragments, acid volcanics, microcline (with perthitic intergrowths), chloritic volcanic rock fragments, and both bryozoan fragments and algal oncolite fragments. The matrix consists of nannoplankton-bearing vitric tuff, some of which contains shallow-water reworked foraminifera mixed with deeper water benthonic foraminifera. In addition, in Sample 286-22-2, $94 \mathrm{~cm}$ a fragment of facies 1 bioturbated siltstone occurs (Figure 15). This facies appears similar to the volcanic conglomerate reported from Site 165 (Winterer, Ewing, et al., 1973, p. 55-59) and shows much in common with the fine-grained rudite facies (Facies D) and the structureless rudite facies (Facies E) reported by Mitchell (1970) from Malekula Island.

Sorting of the conglomerates is very poor. The larger clasts tend to be randomly dispersed and float in a matrix of granules and coarse- to medium-grained tuff. Reverse grading, preserved in intervals ranging from 7 to $26 \mathrm{~cm}$ thick (mean thickness of $13 \mathrm{~cm}$ ), occurs in 28626-2, 110-121 cm and 286-29-4 (Figure 16). The reversed grading consists of either a gradational or a sharp basal contact and ranges from coarse sand at the base to granule gravel at the top. Sorting of the sediments is poor, and coarse-tail grading is common. Medium sand parallel laminae occur within the lower portion of the reversed graded-bedded zones (Figure 16).

The interbedded facies 1 sandstones are characterized by vertical dewatering pipes, particularly in sandstones underlying the conglomerates.

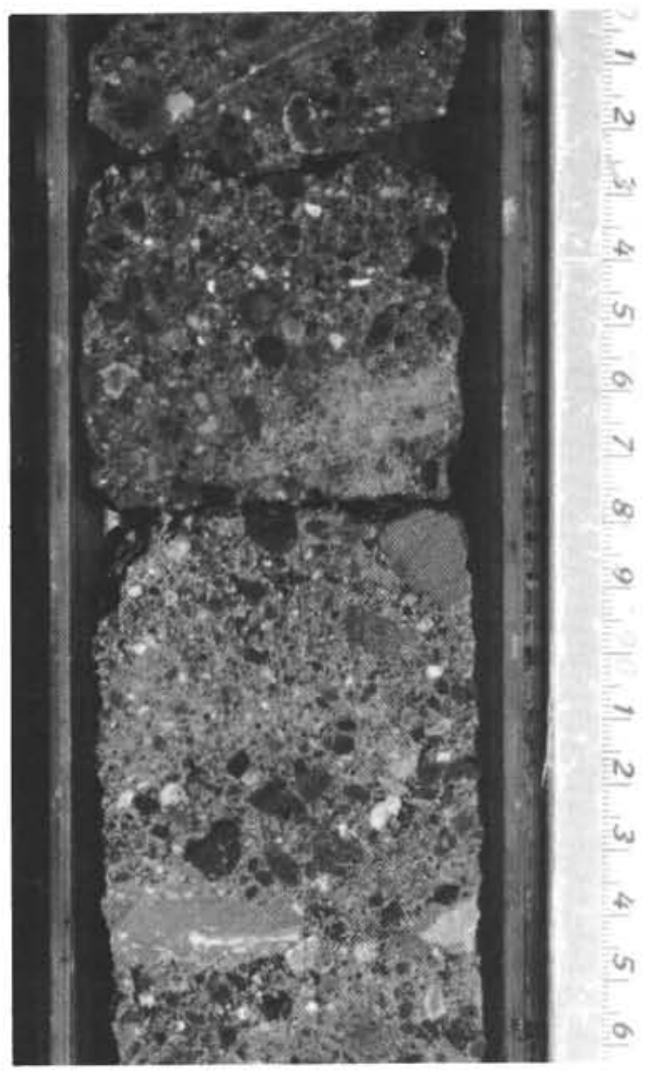

Figure 15. Volcanic conglomerate containing clasts of andesite, pumice, and volcanic rock fragments as well as intraformational clasts (opposite $94 \mathrm{~cm}$ ) and bryozoa and foraminifera fragments (white spots). Facies 2. 286-22-3. Scale in $\mathrm{cm}$.

Biogenic components in this facies include nannofossils and foraminifera. In Samples 286-20, CC; 28621, CC; 286-23, CC; 286-21-2, 140-144 cm; 286-22-2, 64$71 \mathrm{~cm} ; 286-26-3,38-40 \mathrm{~cm}$; and 286-26-4, 131-136 cm littoral-neritic forams such as Asterigerina and Amphistegina are mixed with upper middle bathyal forms. In 286-21-2, 140-144 cm, Lepidocyclina, a shallow-water 


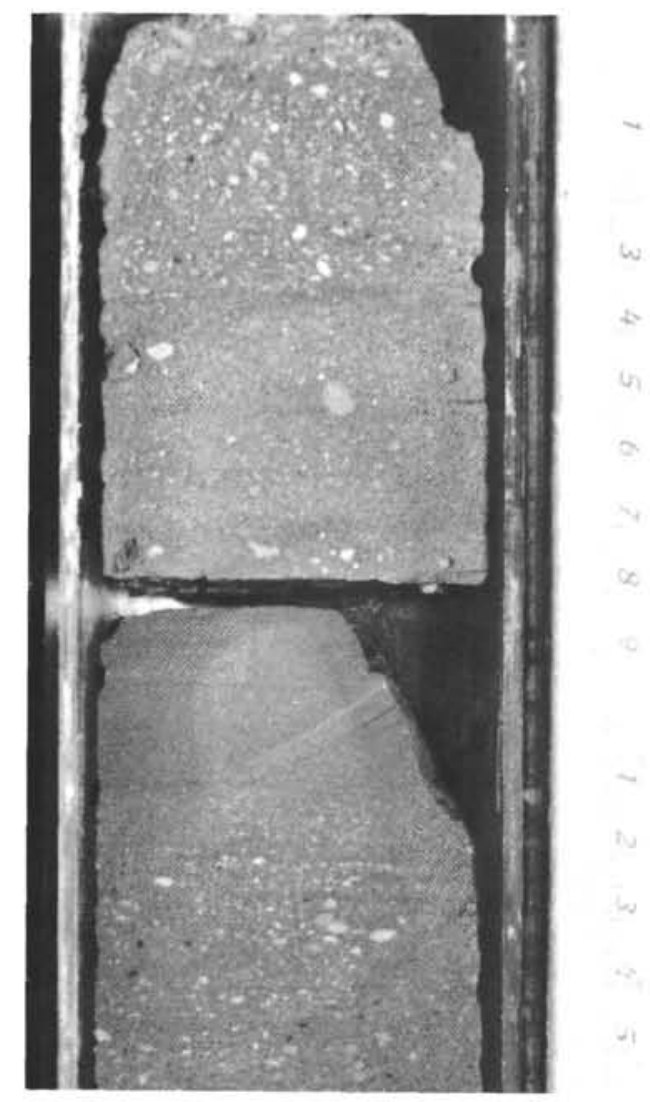

Figure 16. Granule conglomerate showing both normal content grading and parallel laminae (lower) and reverse coarsetail grading and parallel laminae (upper). Facies 2. 286-2. Scale in $\mathrm{cm}$.

larger foraminifera, is mixed with deep-water foraminifera.

\section{Interpretation}

The interbedding of facies 2 within facies 1 suggests that the depositional environment of facies 2 is a submarine fan setting, as reviewed above. The source of the conglomerates appears to be a shoreline of volcanic islands.

The depositional mechanics of facies 2 is probably one of transport of sediment as mass flow and debris flow with interbedded subaqueous slurries as fluidization occurred by mixing of sediment flow with the ambient fluid through which it moves. Mass flow and debris flow is inferred from poor sorting and the dispersed-clast-fabric of coarse-grained components in poorly sorted vitric tuffs (cf. Klein et al., 1972). Transitions into slurries are inferred from recovered intervals of reverse graded bedding which contain a basal interval of parallel laminae. This combination of sedimentary features indicates a high concentration of sediment supported by matrix strength (Middleton and Hampton, 1973) during deposition. Such sediment transport activity is probably confined to the apical or upper suprafan portions of submarine fans where debris flow processes are common.
Facies 3

\section{Main Facts}

Facies 3 occurs at Sites 285, 286, and 287. It consists of nannoplankton ooze, some containing glass shards and foraminifera. These oozes are pale brown, yellowish-orange, dark yellow-brown, light brownish-gray, brown, grayish-orange, yellowish-gray, light bluishgray, gray, and greenish-gray.

The major components are nannoplankton with accessory glass shards, radiolarians, calcareous spicules, foraminifera, and minimal amounts of pyrite, zeolite, and micarb. Light bluish-gray nanno oozes are characterized by an increase in zeolite content.

This facies is devoid of sedimentary structures except for mottling. At $286-9-2,126-130 \mathrm{~cm}$, a thin interval above a sharp scour consists of foraminiferal sand which is microcross-laminated and parallel laminated. Here, these structures are organized in a sequence identical to the type 3 sequence of facies 1 . These structures contain alternating light and dark laminae because of admixture of volcanic sediment. The foraminifera in these crosslaminated zones are of shallow-water origin. Shallowwater foraminifera also occur in $286-3,23-25 \mathrm{~cm}$; 286-72, 113-115 cm; and 286-8-1, 140-142 cm. In 287-16-1, 53$55 \mathrm{~cm}$ and 287-16-1, 74-75 cm, a reworked Danian planktonic foraminifera, Globorotalia pseudobulloides occurs; in Core 287-11, reworked Eocene nannofossils occur in an Oligocene section. These reworked fossils indicate resedimentation of the nanno oozes, possibly by turbidity currents.

This facies appears to be similar to the pelagic limestone facies (Facies A) reported by Mitchell (1970) from the Malekula Islands.

\section{Interpretation}

Facies 3 was deposited under deep-water conditions above the nanno solution depth and in some cases, above the foraminifera solution depth. Periodic influx of volcanic debris, zeolites, and shallow-water foraminifera and older foraminifera and nannofossils suggests influx of sediments by turbidity currents. Preservation of a type 3 sequence suggests such current systems were dilute. The environment appears to have been basinal at the depths indicated.

\section{Facies 4}

\section{Main Facts}

Facies 4 consists of dusky red and brown silty clay and occurs at Sites 285 and 286, where it is post-Pliocene and Miocene-Pliocene and Pleistocene, respectively.

Although similar in color and texture, composition differs between these two sites; at Site 285 , it is zeolitic and micronodular-rich clay, whereas at Site 286 , it is a nannofossil, glass shard silty clay. Accessory components include quartz, feldspar, magnetite, and volcanic glass at Site 285, and micronodules, zeolites, foraminifera, clay minerals, diatoms, sponge spicules, quartz, and feldspar at Site 286. Reworked benthonic foraminifera, including Elphidium crisium, a shallowwater form, are present in Core 286-2, as are fragments of corroded bryozoa and calcareous algae. 
No sedimentary structures were observed except for a thin set of faint parallel laminae at Site 285. This facies is unfossiliferous at Site 285. It is similar to the red mudstone facies (Facies B) reported by Mitchell (1970) from the Malekula Islands.

\section{Interpretation}

This facies is interpreted to be deep-sea abyssal pelagic clays which were deposited below the nanno solution depth (approximately $4500 \mathrm{~m}$ ) at Site 285, and immediately above the nanno solution depth at Site 286 . During deposition, oxidation potential was positive.

\section{Facies 5}

\section{Main Facts}

Facies 5 occurs at Site 287 in the Coral Sea Basin where it ranges in age from middle Miocene to Pleistocene.

This facies consists of an interbedded succession of soft, very dark greenish-gray silty clay, dark greenishgray silty clay to clay, and medium dark greenish-gray silt to sandy silt. These clays and silts are further interbedded with light greenish-gray nannoplankton ooze (Figure 17). The clastic components are organized into a graded sequence characterized by a sharp base overlain by a sandy silt, overlain in turn by a silty clay and capped by clay. These sequences are repeated successively or separated by graded nannoplankton ooze. The silty sands are nanno-bearing heavy mineral feldspar-rich ashes with a sand content of $60 \%$, whereas the sandy silts contain a mixture of glass shards and feldspar (silt content of $90 \%$ ). The silty clays are feldspar rich, whereas the pure clays consist mostly of glass shards and clay minerals. The nanno oozes contain clay, micarb, volcanic glass, and accessory zeolite.

Except for the rhythmic graded organization of the clastic sediments, no other sedimentary structures were observed probably because of drilling disturbance. The average thickness of each graded rhythm is $27.8 \mathrm{~cm}$ (range 6 to $75 \mathrm{~cm}$ ). Pyrite burrow fills are the only biogenic structures occurring in this facies.

\section{Interpretation}

This facies is interpreted to have been deposited by dilute turbidity currents, most probably being derived from a volcanic terrigenous source and a calcareous source. The main evidence for turbidity currents is the presence of the sharp basal scour at the base of graded rhythms, occurrence of graded rhythms, and the occurrence of associated shallow-water foraminifera mixed into graded nanno oozes (see Chapter 5, Site 287 biostratigraphy, this volume). The terrigenous components within the turbidites were derived from a New Guinea source terrain (see Chapter 5, Site 287, this volume; Burns, Andrews et al., 1973; Gardner, 1970) whereas the calciturbidites interbedded with the clayey turbidites were derived more locally, presumably from adjoining highs at Site 287.

New Guinea appears to be a reasonable source for the turbidites. Similar cycles obtained at Site 210 (Burns, Andrews, et al., 1973), which is closer to New Guinea,

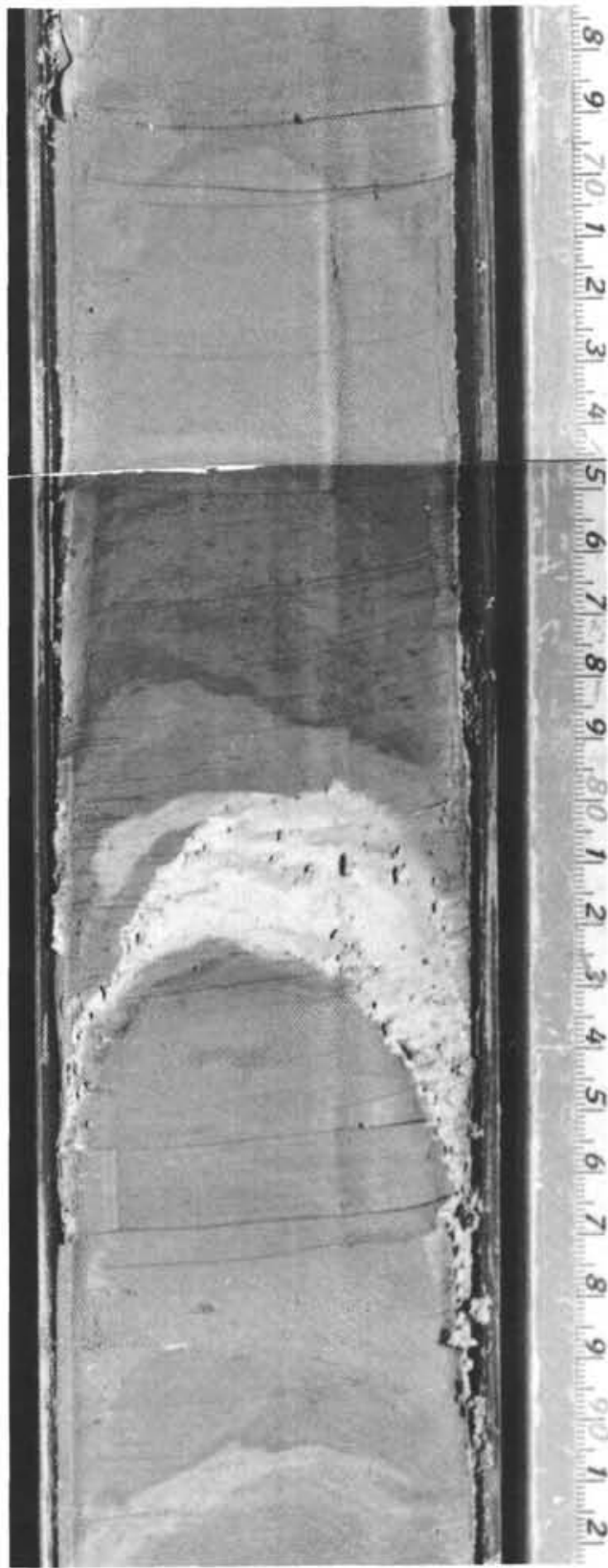

Figure 17. Graded sandy silt, silt, silty clay, and clay interbedded with graded foramnannoplankton ooze. Facies 5. 287-6-4. Scale in $\mathrm{cm}$.

contained coarser sediments, were thicker than at Site 287 , and were more numerous. The increased volume of calciturbidites at Site 287 (compared to Site 210) confirms a more local source for the carbonate fraction.

\section{Facies 6}

\section{Main Facts}

Facies 6 occurs at Site 287 immediately below facies 5 and ranges in age from early to middle Miocene.

This facies consists of grayish-olive and light olive silty clays containing an average clay content of $60 \%$. 
The principal components are clay minerals, volcanic glass, feldspar, zeolite, and unidentified heavy minerals, with accessory micarb and nannofossils. It is classified as a zeolite-feldspar-bearing volcanic glass-rich silty clay. No sedimentary structures are visible. The mineralogy in this facies is identical to the clays in facies 5 .

\section{Interpretation}

Facies 6 owes its origin to turbid clay and silt influxes, perhaps dispersed during an early stage of uplift in New Guinea from which the overlying facies 5 clastics were derived. The facies 6 clays may represent the earliest stage of uplift from this terrain; its age coincides with the time of uplift of eastern New Guinea (Davies and Smith, 1971). Its mineralogical similarity to the overlying facies 5 turbidites suggests a cogenetic history. The dispersal mechanism may be identical to the turbid suspensions reported from offshore California by Drake and Gorsline (1973).

\section{Facies 7}

\section{Main Facts}

Facies 7 occurs at both Sites 288 and 289 where it ranges in age from early Oligocene to Pleistocene, and late Eocene to Pleistocene, respectively. This facies consists of pale brown, light gray, and white calcareous ooze. White is the dominant color. At Site 289, accessory colors include black (mostly as spots or parallel laminae), greenish-white, greenish-gray, yellowish-gray, and medium gray. Trace quantities of pale purple are confined to parallel laminae in the upper part of this facies at Site 289. Examination of selected cores from Sites 288 and 289 within 63 and 50 days after departure from each site, respectively, indicated that the various tints of purple, blue, and green alter to white, and that zones of yellowish-gray change to light yellowish-gray.

Foraminifera and nannofossils comprise the bulk of the total components present, with accessory components including radiolarians and micarb. Trace quantities of feldspar, pyrite, volcanic minerals, heavy minerals, sponge spicules, and silicoflagellates occur. This facies is characterized by a general absence of chert nodules, except for small pebble-size fragments in Cores 289-32, 289-33, and 289-102. At Site 288, this facies also contains thin laminae of dark gray fresh and altered glass, magnetite, pyrite, feldspar, and hornblende.

Sedimentary structures in this facies, where present, consist mostly of color-banded parallel laminae (Figure 18). Dewatering pipes are common in Cores 288A-1 through 6 , where they occur in a slumped zone identified on seismic profiles when the site was approached (see Chapter 6, Site 288 report, this volume). Slump blocks or slump breccia zones are common in this interval also (Figure 19). Slumping within this interval is confirmed from occurrence of displaced foraminifera and nannofossils of shallower water origin than current sampling depth. Radiolarians in Core 288-11 are similarly displaced.

Color-banded lenticular, flaser, and wavy bedding occurs in the lower part of this facies at Site 289.

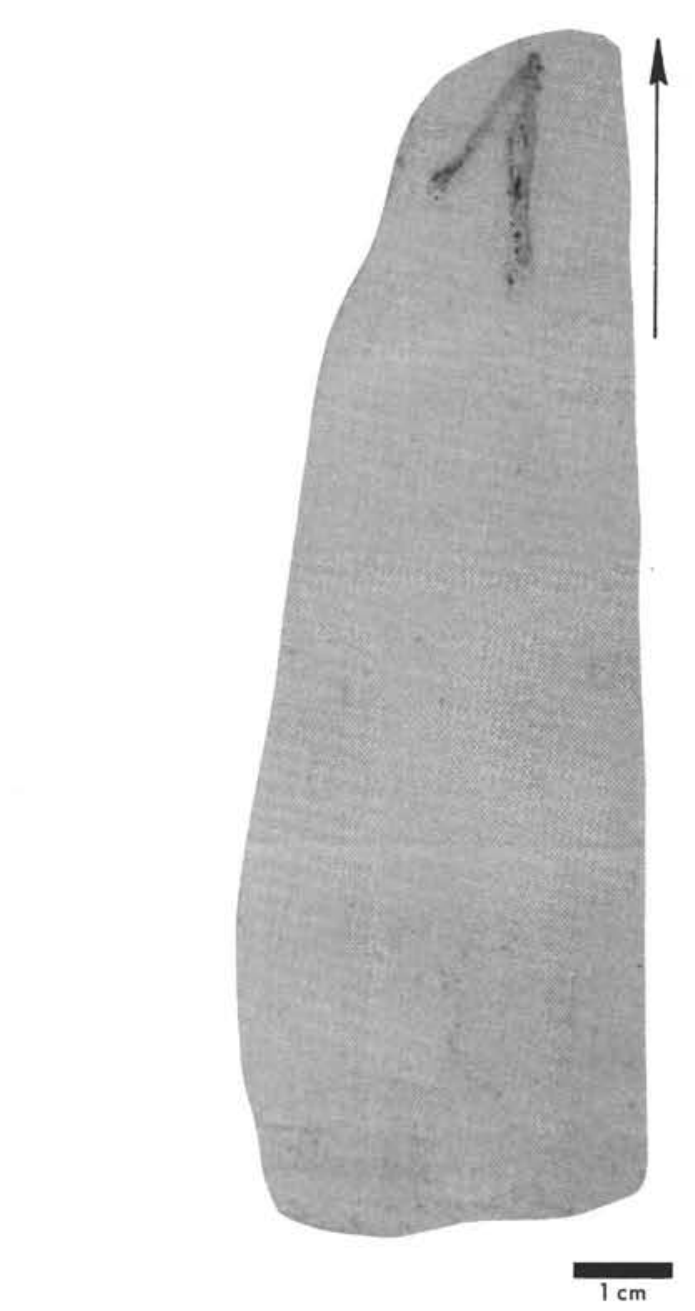

Figure 18. Faint parallel laminae in nannoplankton chalk, Facies 7. Sample 288-9-1, $68-88 \mathrm{~cm}$.

\section{Interpretation}

Facies 7 was deposited above both the foraminiferal and nanno solution depth under conditions of equatorial productivity. These sediments were slumped into deeper water at Site 288 without further solution, perhaps because of rapid burial. No such slumping is indicated for Site 289. In the lower portion of this facies, bottom currents must have reworked some of this sediment and produced a ripple bedform preserved under a clay drape. Preservation of lenticular and flaser bedding, as well as wavy bedded clay drapes, indicates some degree of bottom current activity during the early history of this facies at Site 289, at least of sufficient velocity to produce ripples. The preservation of flaser and wavy-bedded clay drapes suggests possible bottom current transport to be characterized by an alternation of bedload and suspension depositional processes, such as tidal currents. Oceanic bottom currents with both a tidal velocity fluctuation and tidal directional fluctuation have been observed in water depths of 2000 to 2500 meters by Lonsdale et al. (1972a, b) and perhaps similar processes operated on the Ontong-Java Plateau (see also Moore et al., 1973). Perhaps a more long-term periodici- 


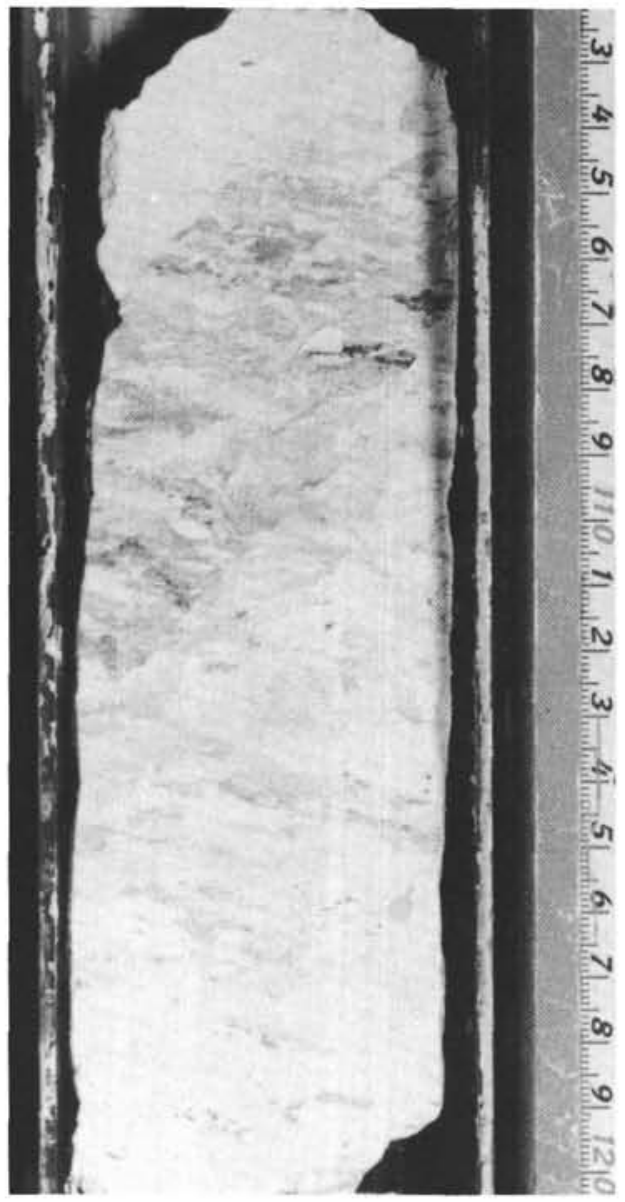

Figure 19. Slumped fragments of bioturbated chalk. Facies 7. 288A-4-1.

ty of alternating bedload and suspension transport is indicated; certainly it is implicit from some of Lonsdale et al. (1972a) observations of stationary bedforms in a lowvelocity regime.

\section{Facies 8}

\section{Main Facts}

Facies 8 occurs at Sites 288 and 289 and ranges in age from Early Cretaceous (Aptian) to early Eocene, and Early Cretaceous (Aptian) to late Eocene, respectively.

This facies consists of interbedded chert nodules, calcareous biogenic ooze, chalk and limestone, volcanic ash, glauconitic layers, and zeolitic-rich clays. The occurrence of chert and volcanic materials is what distinguishes this facies from facies 7 .

The chert nodules in this facies are dark gray, brown, dark reddish-brown, grayish-brown, dark brown, light yellow-brown, medium dark gray, and olive-green. Some nodules show lamination and include isolated spots or vugs of limestone. The chert is in sharp contact with most limestone and chalk, either as a knife-edge or as an interfingering contact (See Chapter 7, Site 289 report, this volume) resembling a graphic granite. The chert is of replacement origin similar to that reported by Heath (1973), Heath and Moberly (1971), and Greenwood (1973).

The chalks and limestones are dominantly of nannofossils and foraminifera. Sandier limestone zones are enriched in foraminifera, or by chalcedony-filled and quartz-filled tests of radiolarians or foraminifera (see Chapter 7, Site 289 report, this volume). In addition, minor traces of micarb, zeolite, calcareous spicules, feldspar, volcanic glass, and magnetite occur. Pyrolusite dendrites occur in Cores 288-24 and 288-25. The chalks and limestones are white, light gray, light yellowishbrown, pink, light brown, and brownish-pink.

At both Sites 288 and 289, the carbonate rocks are interbedded with thin $(1 \mathrm{~mm})$ to thicker $(3 \mathrm{~mm})$ layers of dark brown and dark gray volcanic glass shard siltstones or zeolitic clays. At Site 288 , these siltstones contain either fresh or altered glass. Their distribution appears to be controlled by depositional history and is discussed below with respect to the cycle.

This facies contains many types of sedimentary structures including:

Parallel laminae: Most of the parallel laminae in this facies owe their origin to the occurrence of thin layers (1-3 $\mathrm{mm})$ of interbedded volcanic siltstones and carbonate rock, thus owing their origin to compositional differences. The laminae consist of zeolitic siltstones at Site 289.

Graded bedding: Graded bedding is common to vitric siltstones and occurs with a sharp contact overlying nanno limestones. These graded siltstones range from very fine sand to medium silt (Figure 20). Graded intervals range from 2 to $5 \mathrm{~mm}$.

Wavy bedding: Wavy bedding, following the terminology of Reineck and Wunderlich (1968) occurs in this

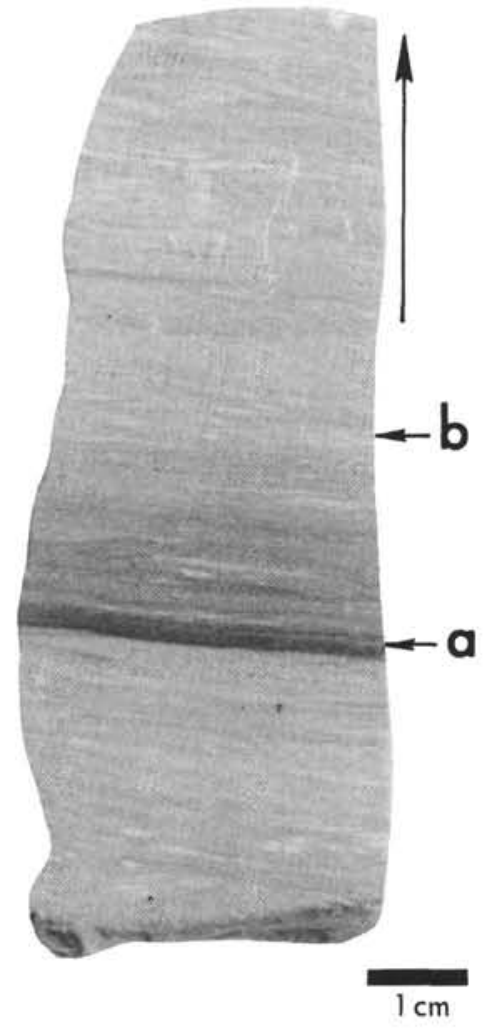

Figure 20. Basal members (" $a$ " and " $b$ " intervals) volcaniclastic-siltstone-pelagic-carbonate cycle consisting of basal graded volcanic ash (dark layer) and limestone with lenticular bedding and clay drapes. Facies 8. Sample 288A-20-2, $37-44 \mathrm{~cm}$. 
facies. The wavy beds are preserved as volcanic glass silty drapes over ripple-like bedforms (Figures 21, 22, 23).

Flaser bedding: This structure occurs commonly in facies 8 . It occurs within lenticular beds as a zeolitic silty clay within nanno limestones. The flasers are olive-gray, light greenish-gray, or medium gray (Figures 21, 22, 23).

Lenticular bedding: This structure is common to both Sites 288 and 289 and is associated with wavy and flaser bedding (Figures 21, 22, 23). The lenses are isolated and are both flat and thick (terminology of Reineck and Wunderlich, 1968). Lense dimensions range in lengths from 3 to $16 \mathrm{~mm}$ and in thickness from 1 to $3 \mathrm{~mm}$. Microcross-laminae occur within the lenses, some brought out by the flaser bedding. These flaser microcross-laminae are greenish-gray, dark gray, or reddishgray and stand in contrast to white, gray, and pink limestones.

At Site 288, the rock types, textures, and sedimentary structures are arranged in a preferred sedimentary sequence or cycle (Figures 20, 24, 25) herein named the volcaniclastic-siltstone-pelagic-carbonate cycle. The base of the cycle is marked by a sharp contact which is overlain by a graded volcanic glass shard siltstone ("a" interval). These siltstones are dark gray and dark brown and range in thickness from 2 to $5 \mathrm{~mm}$ (Figures 20,24). These basal graded siltstones contain fresh glass shards.

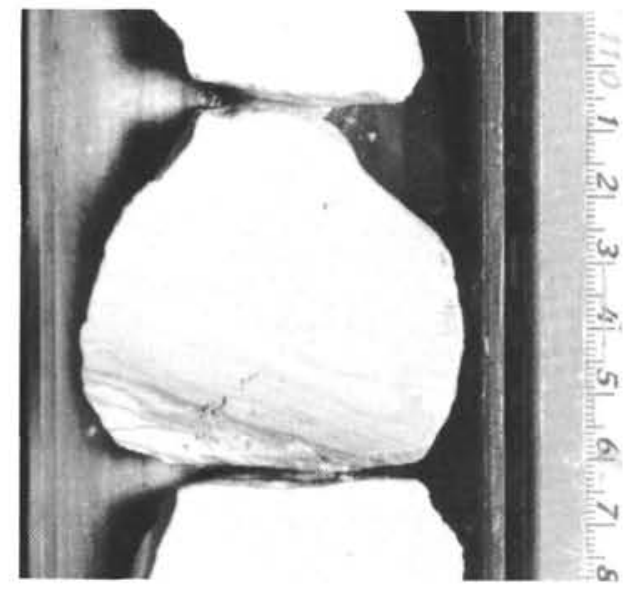

Figure 21. Lenticular bedding in limestone. Facies 8. 288A-15-2. Scale in cm.

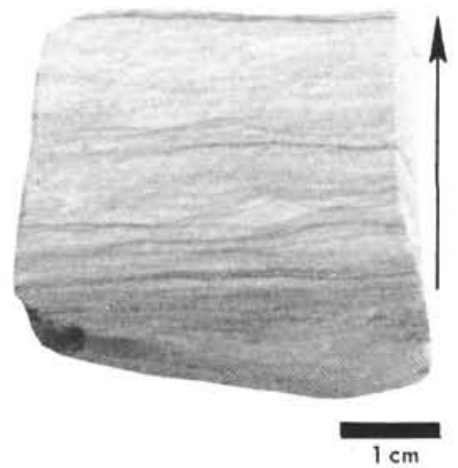

Figure 22. Flaser, lenticular, and wavy bedding. Facies 8 . Sample 288A-21-2, 22-25 cm.

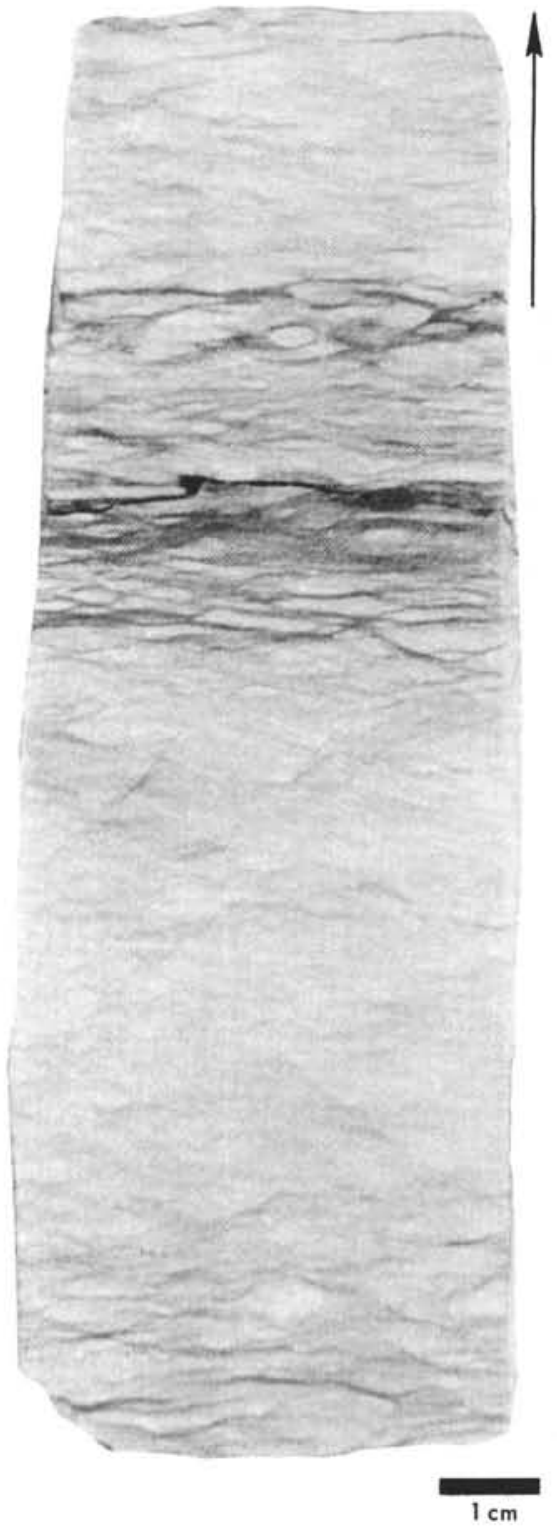

Figure 23. Flaser, lenticular, and wavy bedding. Facies 8. Sample 289-122-1, 119-130 cm.

It is overlain by a " $b$ " interval of biogenic limestone consisting of very fine sand to silt-sized sediments consisting mostly of foraminifera. This second interval contains thin laminae of altered glass shard siltstones and glauconitic siltstones. The altered glass shard siltstone laminae are arranged as parallel laminae and lenticular, flaser and wavy bedding within the limestone. Microcross-laminae also occur within this interval. Chert nodules also appear to be limited to this "b" interval. The cycle is capped by a fine silt-sized, lithographic light gray or pink nannoplankton limestone (Figure 24), designated as interval "c." Complete sequences of the volcaniclastic-siltstone-pelagic-carbonate cycle range from 5 to $100 \mathrm{~cm}$, with an average thickness of $70 \mathrm{~cm}$. Complete sequences occur in Cores 288A-20 and 288A21 , whereas partial sequences of two intervals are preserved in the remaining cores (probably because of poor 


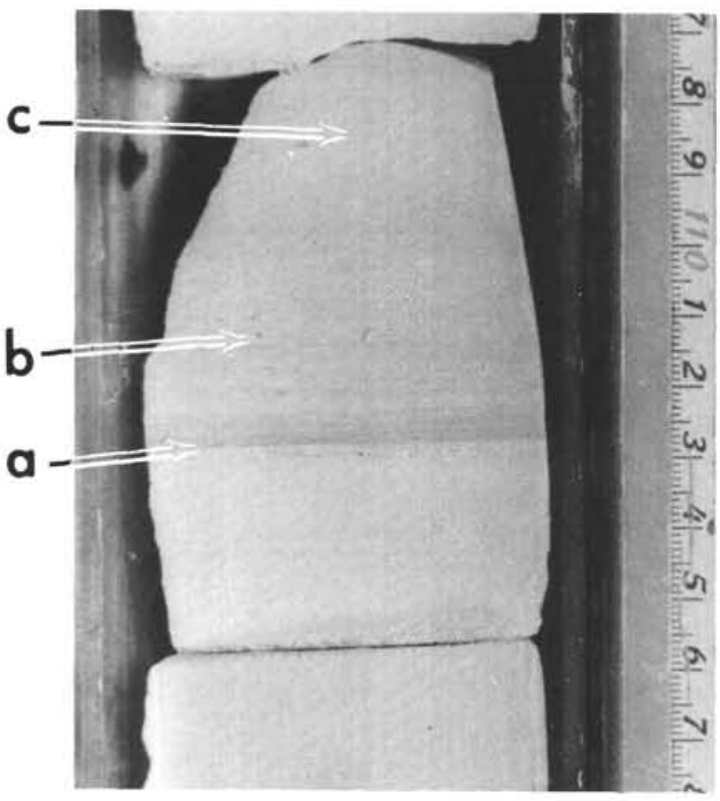

Figure 24. Complete volcanic-carbonate cycle showing basal " $a$ " interval of fresh graded ash, middle " $b$ " interball of parallel-laminated limestone and altered ash, and " $c$ " interval of nannoplankton limestone. Facies 8. 288A-20-1. Scale in $\mathrm{cm}$.
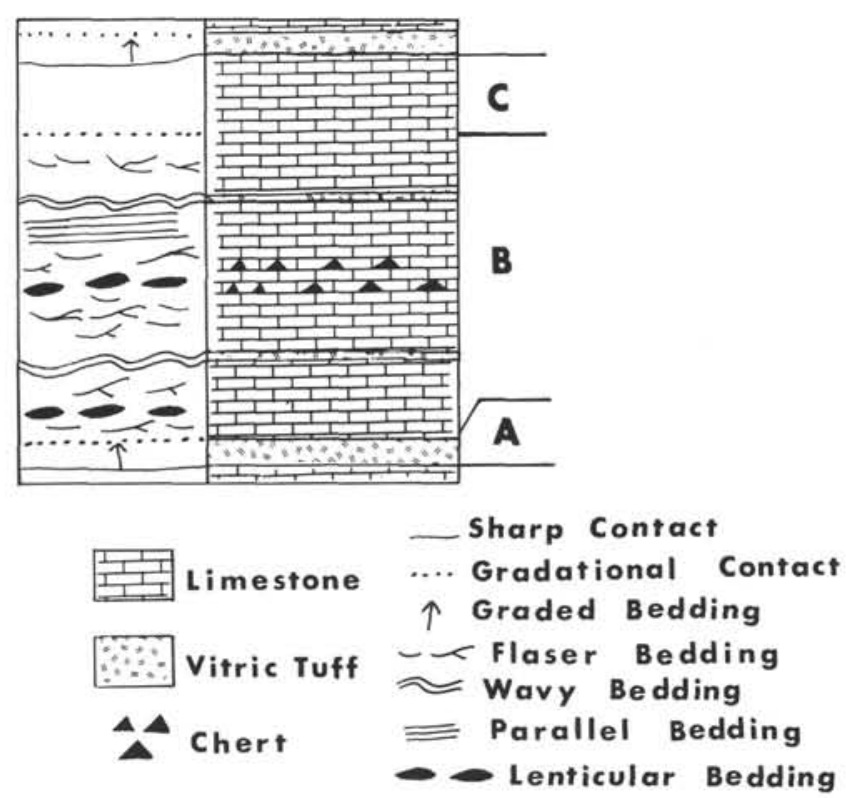

Figure 25. Lithologic and sedimentary structure log of complete volcaniclastic-siltstone-pelagic-carbonate cycle. " $a$ " interval consists of graded fresh volcanic ash or tuff; " $b$ " interval consists of reworked biogenic limestones with interbedded laminae of altered volcanic ash or tuff which drape ripple bedforms and are incorporated as lenticular, flaser, and wavy bedding. Interval " $c$ " consists of nannoplankton limestone. Each cycle is characterized by a sharp base. Chert appears to be confined to interval " $b$ " and occurs as nodules. core recovery). Partial sequences of mixed volcanic siltstone and reworked limestones have been reported from Sites 146/147 (Edgar, Saunders, et al., 1973); Site 165 (Winterer, Ewing, et al., 1973); and Site 312 (Larson, Moberly, et al., 1973).

\section{Interpretation}

This facies was deposited above both the foraminiferal and nanno solution depths and was characterized by an alternating history of biogenic carbonate deposition and influx of volcanic ash. The fresh volcanic ash layers are graded which suggests transport by turbidity currents. The environment was also reworked by other types of bottom currents, which mixed both the biogenic carbonates and the volcanic ashes; this mixing process gave rise to the occurrence of altered ash draped as wavy beds over ripples and preserved as flaser bedding. The currents responsible for segregating carbonate and altered volcanic sediments into this arrangement were characterized by a history of alternating bedload and suspension transport, and as in facies 7 may have resembled tidal currents such as those described from comparable depths of deposition by Lonsdale et al. $(1972 \mathrm{a}, \mathrm{b})$ or represented longer term alternations of relatively low velocity and higher velocity flow. During the redeposition phase, the reworked volcanic ash was altered. Chert replacement occurred subsequent to these events, but appears to be localized to zones where altered ash is interbedded with carbonate sediments. Perhaps alteration of the ash may have occurred in situ and provided the silica for chert diagenesis.

The volcaniclastic-siltstone-pelagic-carbonate cycle owes its origin to the sequential history of these depositional processes. The basal scour accompanied turbidity current deposition which supplied the basal ("a") interval of graded volcanic ash. Reworking of previously deposited biogenic ooze and this ash by bottom currents, perhaps with a tidal flow component or with longer term velocity changes, gave rise to deposition of the "b" interval. The capping lithographic nanno limestone was deposited during periods of low-magnitude current activity which favored normal biogenous sedimentation. The entire cycle was repeated several times; perhaps partial sequences of "a" and "b" reflect minor fluctuation in the nanno solution depth, or repeated scours by subsequent turbidity currents. The partial sequence preserved as interbeds of intervals " $b$ " and "c" were probably deposited beyond the limits of turbidity current emplacement of the fresh, graded ashes.

\section{FACIES SEQUENCES}

The vertical distribution of sedimentary facies recognized in Leg 30 DSDP sediment cores is summarized in Figures 26 and 27. This sequencing is discussed below in terms of the three sites sampled from the South Fiji, Hebrides, and Coral Sea marginal basins, and the two sites from the Ontong-Java Plateau.

\section{Marginal Basins}

At Sites 285 and 286, the vertical sequence of sedimentary facies show remarkable similarities (Figure 

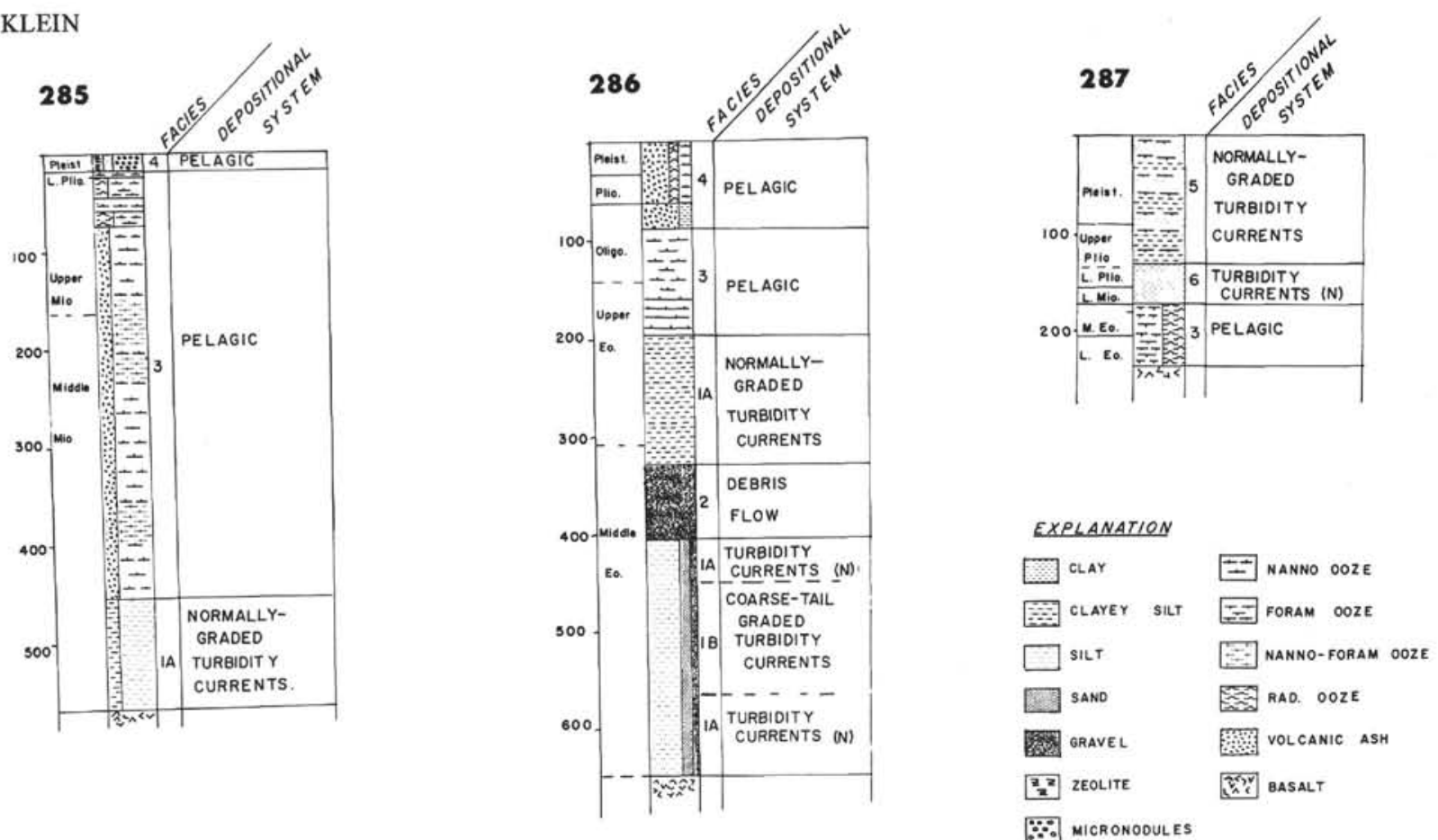

Figure 26. Comparison of vertical distribution of sedimentary facies and associated depositional systems for marginal basin sites $(285,286,287)$. Abbreviation: $(N)=$ normally graded .

26). The basal part of the sequence consists of facies 1 volcaniclastic turbidites overlain by facies 3 carbonate ooze and capped by facies 4 abyssal red clay. Between the two sites, the basalt turbidites show some differences, however. At Site 285, the basal turbidites are content graded (where graded bedding occurs at all) and organized mostly into type 3 sequences. Such types of turbidites are expected, however, at Site 285 because they are located considerably down source $(450 \mathrm{~km})$ from the present position of the Lau Ridge from which they were derived (see Chapter 3, Site 285 report, this volume). Slower rates of deposition and low flow intensity are implied. Coarser volcaniclastic sediments occurred at Site 205 east and north of Site 285, fitting such a source-dispersal interpretation.

At Site 286, the facies sequence differs in that the turbidites are interbedded with the debris-flow and massflow conglomerates of facies 2 . Closer examination of the turbidites of facies 1 at Site 286 (Figure 26) indicates that silty, normally-graded turbidites were deposited during the earlier stages of basin development, whereas turbidites dominated by coarse-tail grading, dewatering pipes, and flame structures were deposited later.

These coarse-tail graded turbidites were emplaced by higher intensity turbidity currents and are interbedded with the mass flow and debris flow conglomerates of facies 2 . The upward increase in progressively coarser turbidites was capped three times by thin layers of debris flow and mass flow volcaniclastic conglomerates, culminating in an episode of extensive debris flow sedimentation (facies 2). These transitions from normallygraded to coarse-tail graded turbidites to mass flow and debris flow deposits mimics the coarsening upward sequences associated with ancient submarine fan deposits reported by Mutti and Ricci-Lucchi (1972) and predicted from progradation of submarine fan subenvironments described by Normark (1970) and Hein (1973). Association of type 2 sequences and type 5 sequences in the horizons immediately below the mass flow and debris flow conglomerates and above the normally-graded turbidites suggests a model of increasing depositional rates and depositional slope angles required to accommodate these processes in such a setting. The turbidites at Site 286 evolved from a more common basinal type to distal fan to suprafan and back again before the onset of biogenic sedimentation.

These two sites suggest a common mode of facies evolution for southwest Pacific marginal bains. Following tectonic extension either by the Karig $(1970,1971)$ model of arc migration, or the Packham, Andrews et al. (Cruise Synthesis, this volume) model of differential plate rotation accompanied by marginal basin development by sea-floor spreading (see also Hayes and Ringis, 1973), basin sedimentation was initiated during an early period of high slope instability which favored transport of volcaniclastic turbidites across the basin. Closer to the basin margins, submarine fans developed (Figure 28 ). As sediment supply is reduced either because of continued extension of the basin (Figure 28), which moved the position of the site away from the basin margin, or reduction of submarine erosion, normallygraded turbidity currents reestablished themselves. Subsequent basinal subsidence following spreading (e.g., Hayes and Ringis, 1973) removed the site locations further away from clastic sources, thus favoring the preservation of biogenic sedimentation in the sequence. Subsidence below the nanno solution depth produced a capping red clay at the two sites.

This type of facies evolution, however, differs from the facies sequence at Site 287 where biogenic oozes 

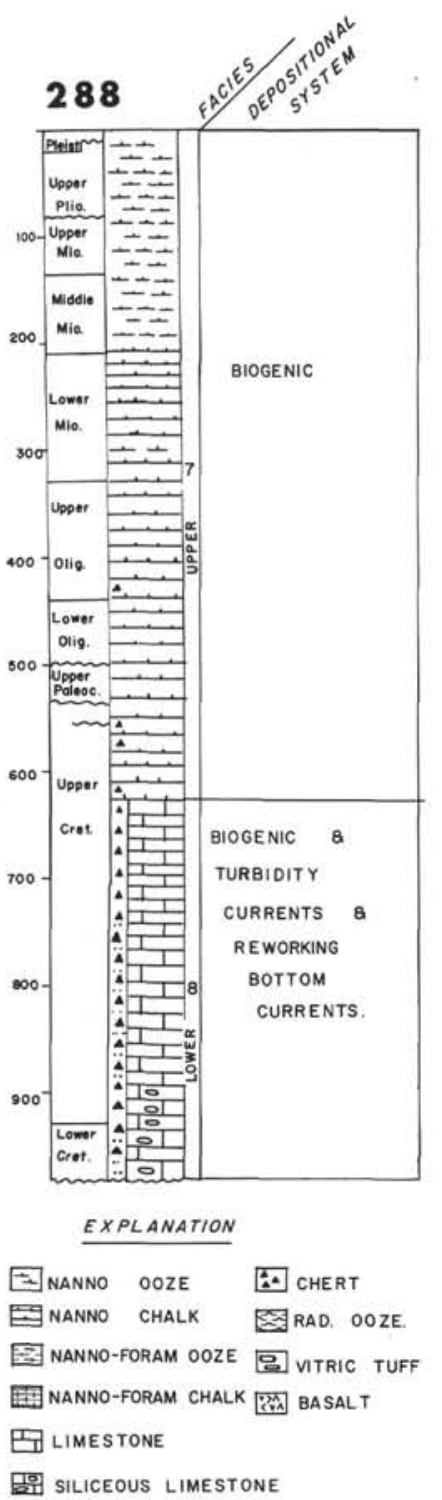

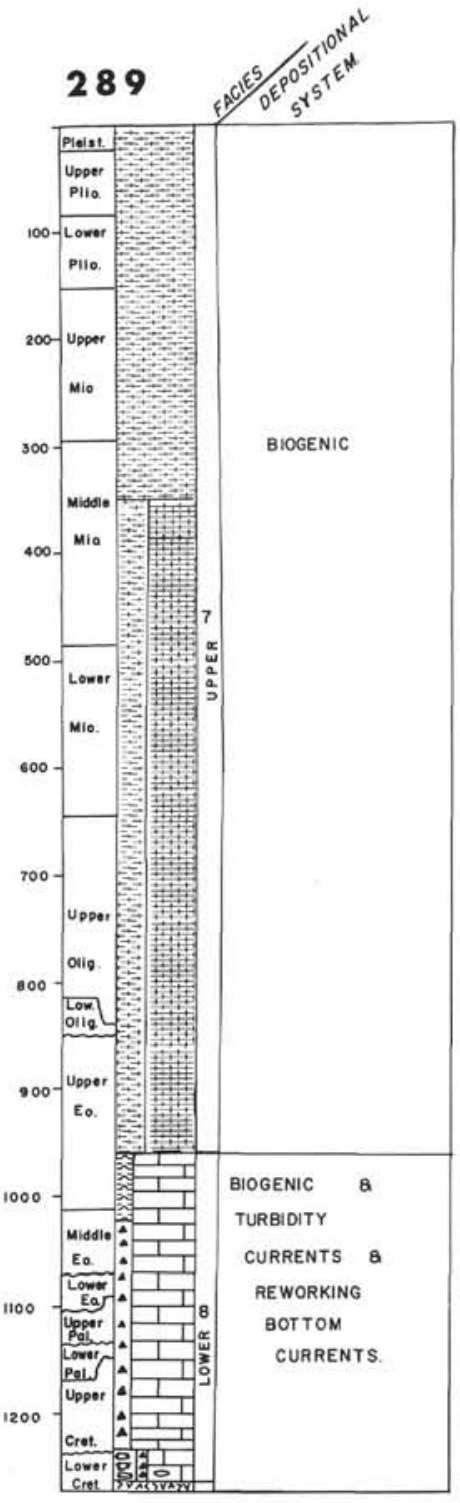

Figure 27. Comparison of vertical distribution of sedimentary facies and associated depositional systems for the Ontong-Java Plateau (Sites 288, 289).

precede deposition of normally-graded, dilute turbidites. There turbidite sedimentation represented by facies 5 and 6 appears to be a consequence of regional uplift of the Owen-Stanley Range, $750 \mathrm{~km}$ to the west in New Guinea during early Miocene time (Davies and Smith, 1972; see Chapter 5, Site 287 report, this volume) rather than because of changes in basin tectonics itself. This uplift episode appears also to have formed a clastic wedge on the north side of the Coral Sea, as implied by data dealing with Holocene sediment distribution reported by Gardner (1970, p. 2602-2606). Here then, basin evolution began with a period of extension and subsidence, following which carbonate sedimentation occurred. Only regional uplift on the margin of the basin increased terrigenous supply to the basin; thus the facies sequence was reversed.

The facies evolution when contrasted between Sites 285 and 286 with respect to 287 may represent, perhaps, a continuum of tectonic sedimentary events. Figure 28 shows an idealized sequence of evolution of a marginal basin. In the earliest stages when extension is dominant, slope instability is high, favoring turbidite and debris flow sedimentation on the basin margins (cf. also Jones, 1967). As extension continues, the source of clastic debris becomes removed from the basin center by regional spreading from a basinal axis, as confirmed from the Tasman Sea by Hayes and Ringis (1973). As basinal slopes are reduced, deposition of sediment by normally-graded turbidity currents is favored. A combination of spreading and vertical movements within the basin aided in separating depositional sites from sourcedispersal systems, effectively shutting off volcaniclastic supply. At this stage, biogenic pelagic processes add sediment exclusively. If a marginal basin should form rapidly, however, basin center regions could become located rapidly beyond the zone of clastic dispersal, and 


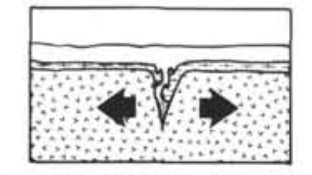

a. Plate Splitting, Sediment Collapse.

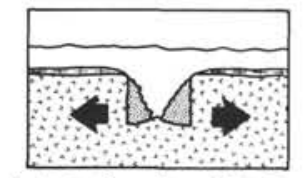

b. Early Spreading, High Slope Gradients; Coarse-grained Turbidity Currents \& Debris Flow.
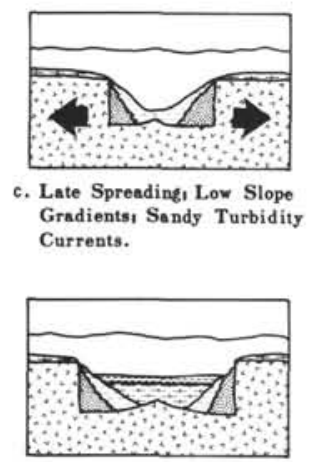

d. Spreading Ceasesı Pelagic Sed i mentation.

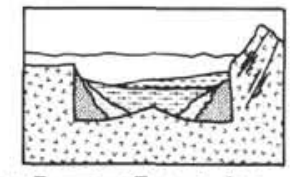

e. Resurgent Tectonic Stage, Deposition of Turbidite Clastic Wedge.

Figure 28. Summary diagram illustrating proposed sedimentary evolution of a marginal basin. (a) Initial rifting and slumping of surface sediment. (b) Early spreading stage favoring deposition of coarse turbidites (1B) and debris flow sediments on surfaces with high slope angles. (c) Late spreading stage favoring deposition of normallygraded sandy turbidites (1A). (d) Pelagic deposition following cessation of basin spreading. (e) Deposition of clayey turbidites during resurgent tectonics along basin boundary. Sites 285 and 286 record events shown for stages 1, 2, 3, and 4. Site 287 appears to record events shown in stage 5. (Numbers in explanatory code refer to facies number used in text.)

therefore time-synchronous biogenic sedimentation could occur. As a consequence, a basin center succession would contain only biogenic sediments, or if renewed vertical uplift occurred, as in the Coral Sea Basin, a capping clastic wedge of turbidites would be deposited. If this model were operative, then the basin margins should show a succession more like that at Sites 285 and 286. The Coral Sea Basin was penetrated by a basinal margin site (Site 209), and it shows a basal calcareous silty sand to sandy volcanic ash mixed with shallowwater carbonates (Burns, Andrews, et al., 1973); this observation clearly leaves the problem open.

\section{Comparison of Leg 30 Basin Facies with an Ancient Island Arc Facies}

It was observed earlier that many of the basin facies reported herein, particularly facies $1,2,3$, and 4 , compare favorably with the sedimentary facies reported by Mitchell (1970) from the Matanui Group (lower Miocene) and the Port Sandwich Formation (middle Miocene) on Malekula Island in the New Hebrides Island arc chain, $90 \mathrm{~km}$ east of Site 286. Although similarity between individual facies classes is apparent, differences in facies sequencing occurs (see Mitchell, 1970, p. 210-211; fig. 5 and 6), primarily because other types of facies recognized by Mitchell (1970) do not occur at Sites 285,286 , and 287 . These other facies consist mostly of carbonate conglomerates and breccias derived from reef flanks and transported and deposited mostly as reef talus or reworked reef talus. In the Matanui Group, Mitchell's graded sandstone facies, which compares favorably with the coarse-tail graded turbidites of facies 1 , are interbedded with graded carbonate beds or several types of reef talus. These Malekula Island sedimentary rocks clearly occur on the frontal arc zone of island arcs and differ mainly through lack of the associated structures reported in facies 1 , the cyclicity of several facies 1 sequences, and the occurrence of variable carbonate breccia and conglomerate facies. Interbedded pelagic limestones (comparable to facies 3) and red mudstone (comparable to facies 4) occur rarely at Malekula Island (Mitchell, 1970, p. 223, table 2) and certainly comprise no more than $0.1 \%$ of the entire stratigraphic section he studied. The marginal basins, then, share in common with the frontal island arc zones the occurrence of coarse-tail and normally-graded turbidites, pelagic oozes, and oceanic red clays, but differ in the relative amounts of each type, and differ also in lacking reef flank and reef talus sediments.

\section{Equatorial Plateau}

The facies sequences in the Equatorial Plateau environment according to data from Sites 288 and 289 are relatively simple (Figure 27). Here, facies 8 carbonates and volcanics which are partly replaced by chert are overlain by nearly pure biogenic carbonate ooze and chalk of facies 7. This facies sequencing would also appear to occur at DSDP Site 64 which is also on the Ontong-Java Plateau (Winterer et al., 1971). The facies of the Equatorial Plateau environment indicate nearly continuous biogenic carbonate sedimentation. However, the earliest stages involve addition and admixing of volcanic debris by turbidity currents, which were subsequently reworked by bottom currents, possibly with a tidal component, as outlined by Lonsdale et al. (1972a, b) and Moore et al. (1973). Periodic breaks in sedimen- 
tation occurred, probably due to the action of corrosive colder currents as proposed by Kennett et al. (1972).

\section{CONCLUSIONS}

The following conclusions can be drawn concerning the depositional facies sampled during Leg 30 .

1) Different types and associations of depositional facies are recognized from three marginal basins and two sites obtained on an equatorial plateau. Their distribution is controlled by differences in tectonic setting.

2) In two of the marginal basins (South Fiji and Hebrides basins), a facies sequence of basal turbidites, medial biogenic carbonates, and uppermost abyssal red clay occur. In a third basin (Coral Sea Basin), the sequence consists of basal biogenic carbonate, capped by silty clayey turbidites.

3) The difference in facies sequence between the South Fiji and Hebrides basin sediments and those from the Coral Sea appears to be a function of distance of site from basin margin volcanic sources, decreasing slope of the depositional sequences with time, distance of sample sites from basin margins, and, in the case of the Coral Sea Basin, later vertical tectonics.

4) The depositional facies obtained at Sites 285,286 , and 287 differ from sedimentary facies described from an ancient island arc system at Malekula Island (Mitchell, 1970) by containing less rudaceous material, less volcaniclastic material, and more sediments deposited by turbidity currents and by pelagic processes.

5) The depositional facies on the Ontong-Java Plateau suggest continuous to near continuous biogenic sedimentation, starting with an earlier phase of mixed sedimentation of biogenic materials and volcaniclastic materials, and ending with nearly volcanic-free sedimentation. Reworking of biogenic sediment by bottom currents, perhaps acting with a tidal component as suggested by Lonsdale et al. (1972a, 1972b) for similar water depths are indicated.

\section{ACKNOWLEDGMENTS}

I wish to thank my colleagues on Glomar Challenger for suggestions and discussions and L.D. Kulm, E.F. McBride, and R.G. Walker for critically reviewing an earlier manuscript version of this paper. A.A. Eckdale identified some of the trace fossils. This paper was completed while the author held an Associateship at the Center for Advanced Study, University of Illinois, and while serving as a Visiting Professor of Oceanography at the School of Oceanography, Oregon State University.

\section{REFERENCES}

Bouma, A.H., 1962. Sedimentology of some flysch deposits: Amsterdam (Elsevier). 1972. Fossil contourites in Lower Niessenflysch, Switzerland: Sediment. Petrol., v. 42, p. 917-921.

Burns, R.E., Andrews, J.E., et al., 1973. Initial reports of the Deep Sea Drilling Project, Volume 21: Washington (U.S. Government Printing Office).

Collinson, J.D., 1969. The sedimentology of the Grindslow Shales and the Kinderscout Grit: a delatiac complex in the Namurian of northern England: J. Sediment. Petrol., v. 39, p. 194-221.

Davies, H.L. and Smith, I.E., 1971. Geology of eastern Papua: Geol. Soc. Am. Bull., v. 82, p. 3299-3312.
DeRaaf, J.F.M., Reading, H.G., and Walker, R.G., 1965. Cyclic sedimentation in the Lower Westphalian of North Devon, England: Sedimentology, v. 4, p. 1-52.

Drake, D.E. and Gorsline, D.S., 1973. Distribution and transport of suspended particulate matters in Hueneme, Redondo, Newport and La Jolla submarine canyons, California: Geol. Soc. Am. Bull., v. 84, p. 3949-3968.

Edgar, N.T., Saunders, J.B. et al., 1973. Initial reports of the Deep Sea Drilling Project, Volume 15: Washington (U.S. Government Printing Office)

Gardner, J.V., 1970. Submarine geology of the western Coral Sea: Geol. Soc. Am. Bull., v. 81, p. 2599-2614.

Greenwood, R., 1973. Cristobalite: its relationship to chert formation in selected samples from the Deep Sea Drilling Project: J. Sediment. Petrol., v. 43, p. 700-708.

Hand, B.M., 1969. Antidunes as trochoidal waves: J. Sediment. Petrol., v. 39, p. 1302-1309.

Hand, B.M., Wessel, J.M., and Hayes, M.O., 1969. Antidunes in the Mount Toby Conglomerate (Triassic), Massachusetts: J. Sediment. Petrol., v. 39, p. 1310-1316.

Hayes, D.E. and Ringis, J., 1973. Seafloor spreading in the Tasman Sea: Nature, v. 243 , p. 454-458.

Heath, G.R., 1973. Cherts from the eastern Pacific, Leg 16, Deep Sea Drilling Project. In Van Andel, Tj.H., Heath, G.R., et al., Initial Reports of the Deep Sea Drilling Project, Volume 16: Washington, (U.S. Government Printing Office), p. 609-614.

Heath, G.R., and Moberly, R.M., Jr., 1971. Cherts from the western Pacific, Leg 7, Deep Sea Drilling Project. In Winterer, E.L. et al., Initial Reports of the Deep Sea Drilling Project, Volume 7: Washington (U.S. Government Printing Office), p. 991-1007.

Heezen, B.C., Hollister, C.D., and Ruddiman, W.F., 1966. Shaping of the continental rise by deep geostrophic contour currents: Science, v. 152, p. 502-508.

Hein, J.R., 1973. Increasing rate of movement with time between California and the Pacific Plate: from Delgada submarine fan source areas: J. Geophys. Res., v. 78, p. $7752-7762$.

Jones, J.G., 1967. Clastic rocks of Espiritu Santo Islands, New Hebrides: Geol. Soc. Am. Bull., v. 78, p. 1281-1288.

Karig, D.E., 1970. Ridges and basins of the Tonga-Kermadec Island Arc System: J. Geophys. Res., v. 75, p. 239-254. 1971. Origin and development of marginal basins in the western Pacific: J. Geophys. Res., v. 76, p. 2542-2561.

Kennett, J.P., Burns, R.E., Andrews, J.E., Churkin, M., Davies, T.A., Dumitrica, P.A., Edwards, A.R., Galehouse, J.S., Packham, G.H., and van der Lingen, G.J., 1972. Australian-Antarctic continental drift, paleocirculation changes and Oligocene deep-sea erosion: Nature, v. 239, p. $51-55$.

Klein, G. deV., deMelo, U., and Della Favera, J.C., 1972. Subaqueous gravity processes on the front of Cretaceous deltas, Reconcavo Basin, Brazil: Geol. Soc. Am. Bull., v. 83 , p. $1469-1492$.

Larson, R.L., Moberly, R., Bukry, D., Forman, H.P., Gardner, J.V., Lancelot, Y., Luterbacher, H.P., Marshall, M., Matter, A., and Vincent, E., 1973. Preliminary results from Deep Sea Drilling Project Leg 32 in the western North Pacific: Geol. Soc. Am. Abstracts with Programs, v. 5, p. 708-709.

Lonsdale, P., Malfait, B.T., and Spiess, F.N., 1972a. Abyssal sand waves on the Carnegie Ridge: Geol. Soc. Am. Abstracts with Programs, v. 4, p. 579-580.

Lonsdale, P., Normark, W.R., and Newman, W.A., 1972b. Sedimentation and erosion on Horizon Guyot: Geol. Soc. Am. Bull., v. 83, p. 289-316.

Middleton, G.V. and Hampton, M.A., 1973. Mechanics of flow and deposition. In Middleton, G.V. and Bouma, A.H. 
(Eds.), Turbidites and deep-water sedimentation: Soc. Econ. Paleontol. Mineral. Short Course Manual.

Mitchell, A.H.G., 1970. Facies of an early Miocene volcanic arc, Malekula Island, New Hebrides: Sedimentology, v. 14, p. 201-243.

Moore, J.C., 1974. Turbidites and terrigenous muds. In Simpson, E.S.W., Schlich, R., et al., Initial Reports of the Deep Sea Drilling Project, Volume 25: Washington (U.S. Government Printing Office), p. 441-480.

Moore, T.C., Jr., Heath, G.R., and Kowsmann, R.O., 1973. Biogenic sediments of the Panama Basin: J. Geol., v. 81, p. $458-472$.

Mutti, E., and Ricci-Lucchi, F., 1972. Le torbiditi dell'Appenino settentrionale: introduzione all 'abalsi di facies: Mem. Soc. Geol. Italiana, v. 11, p. 161-199.

Normark, W.R., 1970. Growth patterns of deep-sea fans: Am. Assoc. Petrol. Geol. Bull., v. 54, p. 2170-2195.

Provo, L.J., 1973. Antidune wave sequences in a Devonian turbidite: Unpublished M.S. Thesis, University of Illinois, Urbana.

Reineck, H.E. and Wunderlich, F., 1968. Classification and origin of flaser and lenticular bedding: Sedimentology, v. 11, p. 99-104.
Shepherd, R.G., Crawley, R.A., and McBride, E.F., 1973. Origin of parallel near-horizontal laminae by bed form migration in a small flume: Geol. Soc. Am. Abstracts with Programs, v. 5, p. 804-805.

Simons, D. B., Richardson, E.V., and Nordin, C.F., Jr., 1965. Sedimentary structures generated by flow in alluvial channels. In Middleton, G.V. (Ed.), Primary sedimentary structures and their hydrodynamic interpretation: Soc. Econ. Paleontol. Mineral. Spec. Pub. No. 12.

Southard, J.B., 1971. Representation of bed configuration in depth-velocity-size diagrams: J. Sediment. Petrol., v. 41, p. 903-913.

Walker, R.G., 1966. Shale Grit and Grindslow Shales: transition from turbidite to shallow water sediments in the Upper Carboniferous of northern England: J. Sediment, Petrol., v. 36 , p. $90-114$.

Winterer, E.L., et al., 1971. Initial Reports of the Deep Sea Drilling Project, Volume 7: Washington (U.S. Government Printing Office).

Winterer, E.L., Ewing, J.I., et al., 1973. Initial Reports of the Deep Sea Drilling Project, Volume 17: Washington (U.S. Government Printing Office). 